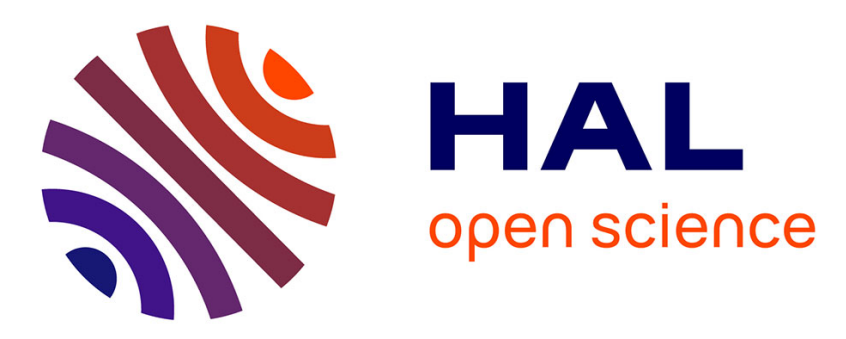

\title{
Ethylene Glycol Electrooxidation on Smooth and Nanostructured Pd Electrodes in Alkaline Media
}

Claudio Bianchini, Pei Kang Shen, Francesco Vizza, Lianqin Q. Wang, Valentina Bambagioni, Manuela Bevilacqua, Jonathan Filippi, Andrea Marchionni

\section{To cite this version:}

Claudio Bianchini, Pei Kang Shen, Francesco Vizza, Lianqin Q. Wang, Valentina Bambagioni, et al.. Ethylene Glycol Electrooxidation on Smooth and Nanostructured Pd Electrodes in Alkaline Media. Fuel Cells, 2010, 10 (4), pp.582. 10.1002/fuce.200900120 . hal-00552360

\author{
HAL Id: hal-00552360 \\ https://hal.science/hal-00552360
}

Submitted on 6 Jan 2011

HAL is a multi-disciplinary open access archive for the deposit and dissemination of scientific research documents, whether they are published or not. The documents may come from teaching and research institutions in France or abroad, or from public or private research centers.
L'archive ouverte pluridisciplinaire HAL, est destinée au dépôt et à la diffusion de documents scientifiques de niveau recherche, publiés ou non, émanant des établissements d'enseignement et de recherche français ou étrangers, des laboratoires publics ou privés. 


\section{Ethylene Glycol Electrooxidation on Smooth and Nanostructured Pd Electrodes in Alkaline Media}

\begin{tabular}{|c|c|}
\hline Journal: & Fuel Cells \\
\hline Manuscript ID: & fuce. $200900120 . R 2$ \\
\hline Wiley - Manuscript type: & Original Research Paper \\
\hline $\begin{array}{r}\text { Date Submitted by the } \\
\text { Author: }\end{array}$ & 23-Nov-2009 \\
\hline Complete List of Authors: & $\begin{array}{l}\text { Bianchini, Claudio; CNR, ICCOM } \\
\text { Shen, Pei Kang; Sun Yat-Sen University, School of Physics and } \\
\text { Engineering } \\
\text { Vizza, Francesco; CNR, ICCOM } \\
\text { Q. Wang, Lianqin; Sun Yat-Sen University, School of Physics and } \\
\text { Engineering } \\
\text { Bambagioni, Valentina; CNR, ICCOM } \\
\text { Bevilacqua, Manuela; CNR, ICCOM } \\
\text { Filippi, Jonathan; CNR, ICCOM } \\
\text { Marchionni, Andrea; CNR, ICCOM }\end{array}$ \\
\hline Keywords: & $\begin{array}{l}\text { Ethylene glycol electro-oxidation, Electrocatalyst, Pd } \\
\text { electrocatalysts, In situ spectroelectrochemical FTIR studies, Cyclic } \\
\text { voltammetry }\end{array}$ \\
\hline
\end{tabular}

\section{s ScholarONE" \\ Manuscript Central}




\title{
Ethylene Glycol Electrooxidation on Smooth and Nanostructured Pd Electrodes in Alkaline Media
}

\author{
V. Bambagioni ${ }^{1}$, M. Bevilacqua ${ }^{1}$, C. Bianchini ${ }^{1 *}$, J. Filippi ${ }^{1}$, A. Marchionni ${ }^{1}$, F.Vizza ${ }^{1 *}$, L. Q. Wang ${ }^{2}$, P. K. \\ Shen $^{2 *}$ \\ ${ }^{1}$ Istituto di Chimica dei Composti Organometallici (ICCOM-CNR), Via Madonna del Piano 10, 50019 Sesto \\ Fiorentino, Italy \\ ${ }^{2}$ The State Key Laboratory of Optoelectronic Materials and Technologies, School of Physics and Engineering, \\ Sun Yat-Sen University, Guangzhou 510275, P.R. China
}

[*] Corresponding authors. Tel.: +39 0555225280; fax: +390555225203.

E-mail address: claudio.bianchini@iccom.cnr.it (C. Bianchini); francesco.vizza@iccom.cnr.it (F. Vizza); stsspk@mail.sysu.edu.cn (P.K.Shen)

\begin{abstract}
The electrooxidation of ethylene glycol (EG) has been studied either in situ on a smooth Pd electrode by FTIR spectroscopy or on nanostructured Pd-based catalysts by cyclic voltammetry. The electrooxidation on the Pd electrode is dramatically influenced by the $\mathrm{pH}$. Below $\mathrm{pH} 12, \mathrm{CO}_{2}$ is formed and detected in the thin layer by FTIR, while at higher $\mathrm{pH}$ values glycolate, carbonate and oxalate are formed almost simultaneously at a potential of ca. $0.4 \mathrm{~V} v s$. RHE. Above $0.9 \mathrm{~V}$ glycolate is oxidized to oxalate and carbonate. The nanostructured electrocatalysts $\mathrm{Pd}-(\mathrm{Ni}-\mathrm{Zn}) / \mathrm{C}, \mathrm{Pd}-(\mathrm{Ni}-\mathrm{Zn}-\mathrm{P}) / \mathrm{C}$ and $\mathrm{Pd} / \mathrm{C}$ are much more active than the smooth $\mathrm{Pd}$ electrode (up to $\left.3300 \mathrm{~A}(\mathrm{Pd})^{-1}\right)$ and give different distributions of the oxidation products. $\mathrm{Pd} / \mathrm{C}$ is the most selective catalyst yielding glycolate, while mixtures of glycolate (major $>60 \%)$, oxalate and carbonate are obtained with $\mathrm{Pd}-(\mathrm{Ni}-$ $\mathrm{Zn}) / \mathrm{C}$ or Pd-(Ni-Zn-P)/C. Carbonate is produced by oxidation of both glycolate (major contribution) and oxalate, while the major part of oxalate seems to be produced by the direct oxidation of EG.
\end{abstract}

Keywords: Ethylene glycol electro-oxidation, Pd electrocatalysts, In situ spectroelectrochemical FTIR studies, Cyclic voltammetry

\section{Introduction}

The electrooxidation of ethylene glycol (EG) on different types of electrodes has been intensely studied over the last 25 years [1-16], largely due to the fact that this diol can be an effective fuel in direct fuel cells in both alkaline and acidic media [17-21]. The interest in EG as an electrochemical fuel has been recently enhanced, because it may be produced from abundant and renewable resources such as cellulose [22]. However, despite some promising achievements [17-21,23], direct ethylene glycol fuel cells (DEGFCs) are still a laboratory device that are not commercially available. This unavailability is largely due to a lack of active and stable anode catalysts, generally based on platinum and platinum alloys, and also to the scarcity of suitable electrolytes for the alkaline environment. Indeed, the alkaline environment offers a number of advantages over the acidic one for alcohol oxidation (see list below) [24,25] but traditional alkaline fuel cells (AFCs) with a liquid electrolyte, suffer some insurmountable problems for an effective application (for instance, membrane carbonation).

- Usability of both noble and non-noble metals to manufacture the electrocatalysts.

- Improved kinetics at both cathode and anode, in particular low anodic over-voltages for alcohol oxidation.

- Alcohol cross-over from anode compartment to cathode compartment reduced by electroosmotic drag of hydrate hydroxyl ions.

- Easier water management as water is formed at the anode side where an aqueous solution already exists, while the electro-osmotic drag transports water away from the cathode preventing its flooding.

- $\quad$ Reduced risk of corrosion of the materials, including catalysts and carbons.

- $\quad$ Reduced adsorption of spectator ions that might limit electrocatalysis.

The recent development of efficient and chemically stable anion-exchange membranes (AEMs) [27-39] can address the electrolyte issue in DEGFCs as well as contribute to design a new generation of alcohol oxidation electrocatalysts. For example, Pd may effectively replace Pt in alkaline media [25,38-40] where also non-noble metals are sufficiently stable for electrochemical applications. Therefore, it is likely that Pd may be diluted with 
non-noble metals to prepare smart catalytic architectures that are capable of functioning as anode electrodes for the rapid and stable oxidation of alcohols. This would decrease the cost of the membrane electrode assemblies (MEAs), thus favouring the commereial viability of DEGFC stacks.

Understanding the mechanism of EG electrooxidation on Pd-based electrocatalysts is therefore an important issue for the development of effective DEGFC anodes. Unlike Pt-based electrodes [1-4,7-12,14], a limited number of studies of the electrocatalysis of EG oxidation on Pd-based electrodes has been carried out so far $[5,6,13,15,16,20]$ and no in situ experiment has been ever reported. Aimed at filling this gap, we report here a study of the electrooxidation of EG on different types of Pd electrodes. A smooth Pd metal electrode was used for an in situ FTIR electrospectroscopy analysis of EG oxidation at different $\mathrm{pH}$ values, while cyclic voltammetry $(\mathrm{CV})$ studies have been performed using the nanostructured catalysts $\mathrm{Pd}-(\mathrm{Ni}-\mathrm{Zn}) / \mathrm{C}$ and $\mathrm{Pd}-(\mathrm{Ni}-\mathrm{Zn}-$ $\mathrm{P}) / \mathrm{C}$. These electrocatalysts, obtained by a redox transmetalation process involving the spontaneous deposition of palladium onto Ni-Zn alloys supported on Vulcan XC-72 [40], have already shown remarkable activity for the oxidation of ethanol in both passive and active fuel cells $[38,39]$. For comparative purposes, we have investigated also the EG electrooxidation on a nanostructured $\mathrm{Pd} / \mathrm{C}$ catalyst prepared by chemical reduction of $\mathrm{H}_{2} \mathrm{PdCl}_{4}$ adsorbed onto Vulcan XC-72 [40].

\section{Experimental}

\subsection{Materials and product analysis}

All manipulations, except as stated otherwise, were routinely performed under argon or nitrogen atmosphere. Aqueous solutions were freshly prepared with doubly distilled-deionized water. The electrocatalysts Pd-(Ni$\mathrm{Zn}) / \mathrm{C}$, Pd-(Ni-Zn-P)/C and Pd/C were prepared as previously described [40] (C = Vulcan XC-72). ICP-AES analysis (wt\%) for Pd-(Ni-Zn)/C: Pd 6.4, Ni 9.7, Zn 2.6; for Pd-(Ni-Zn-P)/C: Pd 4.73, Ni 7.45, Zn 0.43; for $\mathrm{Pd} / \mathrm{C}: \mathrm{Pd} 5.2$.

The qualitative/quantitative analysis of the CV cell exhausts was obtained by ${ }^{13} \mathrm{C}\left\{{ }^{1} \mathrm{H}\right\}$ NMR spectroscopy using a Bruker Avance DRX-400 instrument with the chemical shifts relative to external TMS. The calibration curves for the quantitative analysis were obtained using authentic samples of the various products in the appropriate range of concentrations, using 1,4-dioxane as internal standard. Ionic chromatography (IC) was also used to identify and quantify the oxidation products (Metrohm 761 Compact instrument equipped with a Metrosep Organic Acids column).

\subsection{Electrochemical measurements}

\subsubsection{Ink preparation for the CV study}

A portion of each catalyst (about $45 \mathrm{mg}$ ) was introduced into a $5 \mathrm{~mL}$ high-density polyethylene container together with $1.01 \mathrm{~g}$ of water, $65 \mathrm{mg}$ of $\mathrm{KOH}$ (99.99\% Sigma-Aldrich), $0.50 \mathrm{~g}$ of absolute ethanol (99.8\% Fluka) and $0.37 \mathrm{~g}$ of $5 \%$ Nafion $^{\circledR}$ ion-exchange resin in alcohol solution (Sigma-Aldrich). The resulting suspension was sonicated for $30 \mathrm{~min}$ with a Branson 3200 bath. Each suspension was freshly prepared just before carrying out the experiment scheduled. The metal loading on each glassy carbon electrode (vide infra) was determined by weighting the amount of ink deposited on the glassy carbon disk.

\subsubsection{Apparatus for cyclic voltammetry studies}

The cell used for the cyclic voltammetry (CV) experiments was a Kelef cylinder with a $7.2 \mathrm{~mm}$ inner diameter and a $50 \mathrm{~mm}$ outer diameter [40]. The inner volume of the cell was about $1 \mathrm{~mL}$. The working electrode, Glassy Carbon (Sigradur $\left.{ }^{\circledR} \mathrm{G}\right)\left(0.867 \mathrm{~cm}^{2}\right)$, covered by the catalyst, was housed in a cavity at the top end of the cylinder, and the counter electrode was a gold disc placed at the bottom end. The solution contained in a Pyrex flask was previously purged by bubbling $\mathrm{N}_{2}$ and then flushed into the cell by a pressure as low as 0.3 bar of $\mathrm{N}_{2}$. The miniaturized reference electrode, $\mathrm{Ag} / \mathrm{AgCl} / \mathrm{KCl}_{\text {sat }}$, was placed on the outlet tubing. This design allows one to avoid contamination and at the same time is sufficiently close to the working electrode to reduce the uncompensated resistance. All CV studies were carried out using a Parstat 2277 potentiostat-galvanostat (Princeton Applied Research).

\subsection{In situ FTIR spectroelectrochemical study}

A cell equipped with a $\mathrm{CaF}_{2}$ window was used for the electrochemical and in situ FTIR measurements. The working electrode was a palladium electrode with a $6 \mathrm{~mm}$ diameter. A platinum foil and an $\mathrm{Hg} / \mathrm{HgO}$ electrode were used as the counter and reference electrode, respectively. The electrochemical measurements were performed on a 263A potentialstat/galvanostrat (EG\&G-PARC, USA), connected to the FTIR spectrometer 
(Nicolet 5700 with DTGS detector, Thermo Electron Corporation, USA). The measurements were carried out at $25^{\circ} \mathrm{C}$. The EG concentration was fixed at $1 \mathrm{M}$. Electrolytes with different $\mathrm{NaOH}$ concentrations were used to investigate the $\mathrm{pH}$ effect on the $\mathrm{EG}$ electrooxidation. When necessary, $\mathrm{NaClO}_{4}$ was added to the $\mathrm{NaOH}$ solutions to ensure a constant ionic strength. All solutions were purged with nitrogen prior to use. Prior to each experiment, the palladium electrode was polished with alumina powder, followed by a supersonic rinsing in pure water and a potential cycling in $0.1 \mathrm{M} \mathrm{HClO}_{4}$ at $0.1 \mathrm{~V} \mathrm{~s}^{-1}$ between $0.242 \mathrm{~V}$ and $1.2 \mathrm{~V} v$ s. SCE with a reductive final potential. Afterwards, the palladium electrode was immersed into the electrochemical cell. During the in situ FTIR spectroelectrochemical experiments, the electrode was pressed against the $\mathrm{CaF}_{2}$ window to form a thin layer solution. Each infrared spectrum was recorded from 128 interferograms at the resolution of $4 \mathrm{~cm}^{-1}$. The reference spectrum $\left(R_{r e f}\right)$ was collected at $0 \mathrm{~V} v s$. RHE. The electrode potentials were increased by $0.1 \mathrm{~V}$ intervals from the reference potential up to $1.2 \mathrm{~V}$. The equilibrium at each potential was achieved in $5 \mathrm{~s}$ before the collection of the sample spectra $\left(R_{\mathrm{s}}\right)$. Each final spectrum was reported using Eq. (1). Accordingly, the negative bands represent the species produced and the positive bands the species consumed.

$$
\frac{\Delta R}{R}=\frac{R_{s}-R_{r e f}}{R_{r e f}}
$$

All the potentials in the figures were quoted with respect to the reversible hydrogen electrode (RHE).

\section{Results and Discussion}

\subsection{In situ FTIR study}

The influence of the $\mathrm{pH}$ on the EG electrooxidation on a smooth Pd electrode was investigated by CV using 1 M EG solutions with different $\mathrm{NaOH}$ concentrations but comparable ionic strengths (Figure 1). From a perusal of this figure one may readily realize that the catalytic activity of the Pd electrode decreases by decreasing the $\mathrm{pH}$, until it almost disappears at $\mathrm{pH} 12$. No activity was detected in neutral or acidic media. This finding has been already observed for the oxidation of ethanol on Pd electrodes and rationalized both experimentally and theoretically [41,42]. In particular, DFT calculations suggest that the dehydrogenation of ethanol to acetaldehyde requires a high $\mathrm{OH}_{\mathrm{ads}}$ coverage of the $\mathrm{Pd}$ surface [42].

Figure 1 here

FTIR spectroscopy was used to gain insight into the mechanism of EG electrooxidation on $\mathrm{Pd}$ at different $\mathrm{pH}$ values (Figure 2). At $\mathrm{NaOH}$ concentrations $\geq 1 \mathrm{M}$, the stretching bands of the glycolate ion at $1580 \mathrm{~cm}^{-1}(\mathrm{C}=\mathrm{O})$ and $1070 \mathrm{~cm}^{-1}(\mathrm{C}-\mathrm{O})$ were clearly observed together with lower-intensity bands at 1410 and $1310 \mathrm{~cm}^{-1}$ assignable to carbonate and oxalate, respectively (Figures 2c-d) [4]. The stretch of the oxalate group expected at $1600 \mathrm{~cm}^{-1}$ is likely masked by the band of glycolate. Consistent with the CV study, increasing the $\mathrm{pH}$ decreases the onset potential of EG oxidation. At $\mathrm{NaOH}$ concentrations $\leq 1 \mathrm{M}$, the characteristic band of $\mathrm{CO}_{2}$ at $2343 \mathrm{~cm}^{-1}$ was observed already at $0.7 \mathrm{~V}[3,4]$. The detection of $\mathrm{CO}_{2}$ suggests that the $\mathrm{pH}$ drops in the thin layer due to the consumption of $\mathrm{OH}^{-}$groups (vide infra). No band due to $\mathrm{CO}$ was detected at any $\mathrm{pH}$ or potential. In this respect, it is worth recalling that the IR detection of $\mathrm{CO}_{\text {ads }}$ is particularly difficult in an alkaline electrolyte [43], especially at the very low concentrations expected in the present case. The occurrence of $\mathrm{C}-\mathrm{C}$ bond breaking of an alcohol with formation of $\mathrm{CO}_{2}$ at relatively low $\mathrm{pH}$ values is in line with previous reports according to which a high $\mathrm{OH}$ coverage of the $\mathrm{Pd}$ surface is essential for releasing carboxylate products by $\mathrm{Pd}-\mathrm{acyl} / \mathrm{OH}$ coupling [38-41].

Figure 3 shows the potential dependence of the integrated intensities of the glycolate $\mathrm{C}=\mathrm{O}(\mathrm{A})$ and $\mathrm{C}-\mathrm{O}(\mathrm{B})$ bands at 1580 and $1070 \mathrm{~cm}^{-1}$, respectively, in the thin layer solution. The onset potential of EG oxidation apparently decreases by increasing the $\mathrm{NaOH}$ concentration and the intensity of either band reaches a maximum at ca. $0.9 \mathrm{~V}$. Above this potential, however, the intensities of these two bands diverge, which can be attributed to an increase of the oxalate band at $1600 \mathrm{~cm}^{-1}$ enhancing the intensity of the glycolate band (see also the increase in intensity of the band at $1310 \mathrm{~cm}^{-1}$ ).

Figure 2 here

Figure 3 here

Overall, the electrooxidation of EG on Pd does not diverge substantially from that on Pt [1-4,7-12,14]: glycolate, oxalate and carbonate seem to form at the same potential with an increase of oxalate and carbonate 
formation at the expense of glycolate above $0.9 \mathrm{~V}$. What really distinguishes $\mathrm{Pd}$ from $\mathrm{Pt}$ is the higher electrochemical activity of the former metal in alkaline media.

The lack of reports in the relevant literature dealing with in situ FTIR studies of EG electrooxidation on Pd does not allow one to make a direct comparison with the present results. However, it is worthwhile to discuss some studies of EG oxidation on Pt electrodes in alkaline media. In view of EMIR spectroscopy, Kardigan et al. have concluded that the adsorption of EG at a Pt electrode is dissociative at any $\mathrm{pH}$ with formation of $\mathrm{CO}_{\text {ads }}[2]$, which contrasts with the behavior of Pd-based catalysts (vide infra). Besides confirming the presence of linearly bonded $\mathrm{CO}$ at high $\mathrm{pH}$ values, a SNIFTIR study by Christensen and Hamnett has shown the formation of glycolate, oxalate and carbonate upon oxidation of EG on Pt in alkaline media [4]. Based on the potential window at which these products were detected as well as the EG concentration, it was suggested that glycolate and carbonate are produced from the same intermediate (e. g. $\mathrm{Pt}-\mathrm{CH}(\mathrm{OH}) \mathrm{CH}_{2} \mathrm{OH}$ ), while oxalate is obtained by oxidation of desorbed glycolate. Likewise, a following SPAIR study of EG electrooxidation on Pt/C, PtPd/C, $\mathrm{PtBi} / \mathrm{C}$ and $\mathrm{PtBiPd} / \mathrm{C}$ electrodes has provided evidence that oxalate is not a primary product of EG oxidation but it comes from adsorption and oxidation of glycolate [20]. Traces of glyoxylic acid and formic acid were also detected by HPLC. Coutanceau et al. have found that the addition of Pd to Pt-base catalysts reduces the amount of strongly adsorbed carbonyl species at Pt, leading to higher current densities by virtue of the low propensity of $\mathrm{Pd}$ to cleave C-C bonds [20]. It was also proposed that Bi exerts a beneficial effect on the onset potential of EG electrooxidation as well as on the catalyst stability by virtue of the greater propensity of Bi to adsorb and activate hydroxyl groups as compared to Pd.

\subsection{CV studies}

The electrochemical activity of the nanostructured catalysts $\mathrm{Pd}-(\mathrm{Ni}-\mathrm{Zn}) / \mathrm{C}, \mathrm{Pd}-(\mathrm{Ni}-\mathrm{Zn}-\mathrm{P}) / \mathrm{C}$ and $\mathrm{Pd} / \mathrm{C}$ for EG oxidation was investigated by $\mathrm{CV}$ at room temperature. A preliminary study was carried out to find suitable conditions in terms of catalyst loading on the electrode and of $\mathrm{KOH}$ concentration. For all catalysts, Pd loadings varying from 24 to $28 \mu \mathrm{g} \mathrm{cm}^{-2}$, corresponding to $18-20 \mathrm{mg}$ of ink, gave the highest current density values in $2 \mathrm{M}$ $\mathrm{KOH}$ at a scan rate of $50 \mathrm{mV} \mathrm{s}{ }^{-1}$. A series of cyclic voltammograms, recorded at $\mathrm{KOH}$ concentrations spanning from 0.01 to $4 \mathrm{M}$, showed the generation of the highest current densities in the range 1.5-2 $\mathrm{M} \mathrm{KOH}$. The following electrochemical studies in half cells were carried out using a $2 \mathrm{M} \mathrm{KOH}$ solution, a proper condition to keep a relatively high $\mathrm{OH}^{-}$concentration during the $\mathrm{CV}$ and chronoptentiometric experiments. Indeed, the oxidation of EG in alkaline media consumes $\mathrm{OH}^{-}$groups, irrespective of the oxidation level of the substrate (glycolate, oxalate or carbonate, Eqs. (1)-(3)).

$$
\begin{aligned}
& \left(\mathrm{CH}_{2} \mathrm{OH}\right)_{2}+5 \mathrm{OH}^{-} \rightarrow \mathrm{CH}_{2}(\mathrm{OH}) \mathrm{COO}^{-}+4 \mathrm{H}_{2} \mathrm{O}+4 \mathrm{e}^{-} \\
& \left(\mathrm{CH}_{2} \mathrm{OH}\right)_{2}+10 \mathrm{OH}^{-} \rightarrow\left(\mathrm{CO}_{2}\right)_{2}^{2-}+8 \mathrm{H}_{2} \mathrm{O}+8 \mathrm{e}^{-} \\
& \left(\mathrm{CH}_{2} \mathrm{OH}\right)_{2}+14 \mathrm{OH}^{-} \rightarrow 2 \mathrm{CO}_{3}^{2-}+10 \mathrm{H}_{2} \mathrm{O}+12 \mathrm{e}^{-}
\end{aligned}
$$

The EG concentration was fixed at $5 \mathrm{wt} \%$ as this value has been found appropriate for DEGFCs with AEMs [44]. On the other hand, a previous CV study of EG electrooxidation on a smooth Pd electrode has demonstrated that the current densities are practically independent on the EG concentration but proportional to the $\mathrm{OH}^{-}$ concentration with a reaction order of ca. 1 [5].

In conclusion, all the $\mathrm{CV}$ measurements reported below were performed at a sweep rate of $50 \mathrm{mV} \mathrm{s}^{-1}$ in deoxygenated $5 \mathrm{wt} \% \mathrm{EG}, 2 \mathrm{M} \mathrm{KOH}$ solutions and electrodes containing a Pd loading between 24 and $28 \mu \mathrm{g} \mathrm{cm}$ 2

Figure 4 shows the cyclic voltammograms of the EG oxidation reaction on $\mathrm{Pd} / \mathrm{C}, \mathrm{Pd}-(\mathrm{Ni}-\mathrm{Zn}-\mathrm{P}) / \mathrm{C}$ and $\mathrm{Pd}-$ $(\mathrm{Ni}-\mathrm{Zn}) / \mathrm{C}$ electrodes.

\section{Figure 4 here}

Relevant electrochemical parameters such as the peak current density $\left(\mathrm{J}_{\mathrm{p}}\right)$, the specific peak current density $\left(\mathrm{Sa}_{\mathrm{p}}\right)$, the forward anodic peak potential $\left(\mathrm{V}_{\mathrm{p}}\right)$, the onset oxidation potential $\left(\mathrm{V}_{\text {onset }}\right)$ and the Tafel slopes, together with the electronic transfer coefficient $\alpha$, are given in Table 1. The three catalysts show high activity for the EG oxidation reaction with onset potentials at ca. $0.4 \mathrm{~V} v s$. RHE and specific current densities higher than $3 \mathrm{~mA}$ $\mu \mathrm{gPd}^{-1}$ for Pd-(Ni-Zn)/C and Pd/C. Accordingly, Pd-(Ni-Zn)/C, Pd-(Ni-Zn-P)/C and Pd/C can be classified amongst the best performing electrocatalysts ever reported for EG oxidation. As expected, the oxidation of EG starts at the potential corresponding to the coverage of the electrode surface by $\mathrm{OH}$ groups $[5,15,16,38,40]$. A specific CV study of the Pd-(Ni-Zn)/C, Pd-(Ni-Zn-P)/C and Pd/C electrodes in $2 \mathrm{M} \mathrm{KOH}$ solution without EG has been previously reported [40] and the corresponding CVs are also shown in Figure 7.

As shown by the traces in Figure 4, the three electrocatalysts are characterized by rather similar activities with $\mathrm{Pd}-(\mathrm{Ni}-\mathrm{Zn}) / \mathrm{C}$ being slightly more active than $\mathrm{Pd} / \mathrm{C}$, especially in terms of forward and backward anodic 
peak potentials. Since we observed for all catalysts a slow but constant decrease of the peak back current with increasing the anodic limit (from 0.9 to $1.6 \mathrm{~V}$ ), the backward scan peak can be associated to the oxidation of freshly chemisorbed EG. In fact, previous CV studies of ethanol oxidation on Pd have shown that the decrease in current at high voltages is mainly due to the formation of a PdO layer, which blocks the adsorption of the substrate [41]. The electrocatalytic activity is restored in the negative-going sweep once the potential reaches the value at which $\mathrm{PdO}$ is reduced to $\mathrm{Pd}$. On the other hand, one cannot rule out that a contribution to the current decrease may be due to mass transfer phenomena as well as the instantaneous shortage of $\mathrm{OH}^{-}$groups in the thin layer. In fact, adsorbed $\mathrm{OH}$ species are required to release the carboxylic acid upon coupling with $\mathrm{Pd}$-acyl species as shown in Scheme 1 [39]. Previous studies of ethanol oxidation on Pd-(Ni-Zn)/C and Pd-(Ni-Zn-P)/C [40] have unambiguously shown that the Ni-based supports, though able to oxidise ethanol in alkaline media, are not directly involved in the ethanol oxidation reaction occurring at the largely negative potentials of the Pdcontaining electrocatalysts. It has been proposed that $\mathrm{Ni}$ increases the amount of $\mathrm{OH}_{\text {ads }}$ groups on the catalyst surface, which would favour the formation of the carboxylic acid by coupling with acyl ads species $[25,40]$

Table 1 here

\section{Scheme 1 here}

Tafel plots for the EG oxidation reaction on the $\mathrm{Pd}-(\mathrm{Ni}-\mathrm{Zn}) / \mathrm{C}, \mathrm{Pd}-(\mathrm{Ni}-\mathrm{Zn}-\mathrm{P}) / \mathrm{C}$ and $\mathrm{Pd} / \mathrm{C}$ electrodes were obtained at a scan rate of $5 \mathrm{mV} \mathrm{s}^{-1}$ in the potential interval from 0.3 to $0.5 \mathrm{~V}(2 \mathrm{M} \mathrm{KOH}, 5 \mathrm{wt} \% \mathrm{EG})$. The values for the Tafel slopes and of the $\alpha$ coefficients (Table 1) are comparable with each other as well as with those reported for nanostructured Pd electrocatalysts supported on the same carbon black, also promoted by metal oxides $[13,15,38,40]$. These values are higher than those reported for a smooth Pd electrode $\left(120 \mathrm{mV} \mathrm{dec}^{-1}\right)$ [5], most likely due to the porous high surface area of the present electrodes $[38,15]$. The Tafel slopes indicate a similar reaction mechanism for the three electrocatalysts, while the $\alpha$ parameter of ca. 0.3 is consistent with an electrochemical rate limiting step for the EG oxidation reaction.

For all electrodes, the anodic peak current density for EG oxidation was plotted against the square-root of the scan rate (Figure 5). A linear relationship, typical of an electrochemical reaction under diffusion control, was found for the Pd-(Ni-Zn)/C and Pd-(Ni-Zn-P)/C electrodes. In contrast, a slightly parabolic curve was observed for the $\mathrm{Pd} / \mathrm{C}$ electrode, which suggests a reaction controlled by the activation polarization. As previously reported for the oxidation of ethanol on a similar $\mathrm{Pd} / \mathrm{C}$ electrode [40], this effect can be related to the very low number of catalytically active sites on the electrode surface due to the low Pd dispersion: just by increasing the metal loading is the reaction controlled by substrate diffusion [40].

The performance stability of the three electrocatalysts for EG oxidation was investigated by chronopotentiometry. Steady state measurements, carried out with a constant current density polarization of 3.46 $\mathrm{mA} \mathrm{cm}$ showed a negligible potential oscillation for 2 hours, indicative of no strongly adsorbed species on the catalyst surface. Notably, the selective formation of glycolate with trace amounts of oxalate and carbonate (Eq. (1)) was determined by ionic chromatography $/{ }^{13} \mathrm{C}$ NMR analysis of the chronopotentiometric exhausts produced by $\mathrm{Pd} / \mathrm{C}$ as electrocatalyst. $\mathrm{Pd}-(\mathrm{Ni}-\mathrm{Zn}) / \mathrm{C}, \mathrm{Pd}-(\mathrm{Ni}-\mathrm{Zn}-\mathrm{P}) / \mathrm{C}$ gave a different product distribution. On both electrocatalysts EG was prevalently converted to glycolate (57-63\%) but appreciable amounts of oxalate (35$30 \%)$ and carbonate $(8-7 \%)$ were also formed, revealing a different chemoselectivity of EG oxidation of the nanostructured catalysts promoted by the $\mathrm{Ni}-\mathrm{Zn}$ and Ni-Zn-P alloys as compared to plain $\mathrm{Pd} / \mathrm{C}$. In no case were glyoxaldehyde or its hemiacetal detected by NMR spectroscopy on the cell exhausts.

The different product distribution provided by $\mathrm{Pd}-(\mathrm{Ni}-\mathrm{Zn}) / \mathrm{C}$ and $\mathrm{Pd}-(\mathrm{Ni}-\mathrm{Zn}-\mathrm{P}) / \mathrm{C}$ as compared to $\mathrm{Pd} / \mathrm{C}$ seems to be inconsistent with a similar reaction mechanism for the three catalysts, as suggested by the Tafel slopes. A clear-cut explanation of this phenomenon is not available at this stage: the rate-determining step seems to be electrochemical in nature but it has not been identified among the several oxidation steps occurring for EG oxidation on the electrode surfaces. On the other hand, a precise quantification of the oxidation products may be inaccurate due to the little EG conversion in the chronopotentiometric experiments.

\section{Figure 5 here}

Overall, the electrooxidation of EG on Pd-(Ni-Zn)/C, Pd-(Ni-Zn-P)/C and Pd/C resembles that of ethanol oxidation on the same electrodes that selectively yields potassium acetate $[39,40]$. Unlike ethanol, however, EG contains two hydroxyl groups so that in alkaline media at least three carboxylate products (glycolate, glyoxylate and oxalate) plus formate and carbonate may be obtained upon electrooxidation (Scheme 2). This scheme illustrates the overall electrochemical oxidation of EG in alkaline media as inferred from a perusal of the literature $[3,4,7,9,11,12,14,20]$ as well as the present results. The scheme includes all the species that have been either isolated (boxes) or detected in situ (circles). 
In an attempt to gain insight into the EG electroxidation on the present nanostructured Pd catalysts, independent $\mathrm{CV}$ experiments have been carried out using solutions of potassium glycolate, potassium glyoxylate and potassium oxalate as anolytes.

The cyclic voltammograms of glycolic acid and glyoxylic acid oxidation on Pd-(Ni-Zn)/C, Pd-(Ni-Zn-P)/C or $\mathrm{Pd} / \mathrm{C}$ in $2 \mathrm{M} \mathrm{KOH}$ are shown in Figure 6.

\section{Figure 6 here}

The glycolate ion is much more difficult to oxidize on Pd than EG as shown by the corresponding $\mathrm{Sa}_{\mathrm{p}}$ values which are one order of magnitude lower than those observed for EG (Figure 6A). Slightly higher current densities are produced by glyoxylate (Figure 6B) which can be an intermediate along the conversion of EG and glycolate to oxalate (Scheme 2). The aldehyde group is oxidized on $\mathrm{Pd}$ at a more negative potential than the alcohol group as shown also by the shoulder at ca. $0.85 \mathrm{~V}$ in Fig. 6 (right) corresponding to the oxidation of the glycolate formed upon disproportionation of the aldehyde in alkaline media. Notwithstanding the low current density observed, there is little doubt that glycolate can be oxidized to oxalate on $\mathrm{Pd}$. On the other hand, just the very low current densities provided by glycolate oxidation on $\mathrm{Pd}-(\mathrm{Ni}-\mathrm{Zn}) / \mathrm{C}$ and $\mathrm{Pd}-(\mathrm{Ni}-\mathrm{Zn}-\mathrm{P}) / \mathrm{C}$ and the fact that both electrocatalysts yield relatively large amounts of oxalate and carbonate indicate that the oxidation of EG on these catalysts proceeds by parallel routes with path c prevailing over paths a-b for oxalate production (Scheme $3)$.

\section{Scheme 3 here}

In an attempt to understand whether oxalate is oxidized to $\mathrm{CO}_{2}$ on the present nanostructured Pd-based electrocatalysts, a CV study has been carried out on an alkaline solution of potassium oxalate. The corresponding cyclic voltammograms are given in Figure 7 that also shows those recorded on $\mathrm{KOH}$ solutions with no substrate. Upon addition of oxalic acid to the latter solutions, a significant decrease of the peak associated to PdO reduction in the reverse scan at ca. $0.65 \mathrm{~V}$ is observed together with an oxidation peak at $0.47 \mathrm{~V}$ featured by a very low specific current. Accordingly, one may conclude that the carbonate formed upon electrooxidation of EG on Pd-(Ni-Zn)/C and Pd-(Ni-Zn-P)/C is prevalently obtained from glycolate with a very minor contribution from oxalate.

Figure 7 here

\section{Conclusions}

The electrooxidation of EG on Pd is dramatically influenced by the $\mathrm{pH}$. Below $\mathrm{pH} 12, \mathrm{CO}_{2}$ is formed and detected in the thin layer by FTIR, while at higher $\mathrm{pH}$ values glycolate, carbonate and oxalate are formed almost simultaneously at a potential of ca. $0.4 \mathrm{~V} v s$. RHE. Above $0.9 \mathrm{~V}$ glycolate is oxidized to oxalate and carbonate.

The electrodes with the nanostructured catalysts $\mathrm{Pd}-(\mathrm{Ni}-\mathrm{Zn}) / \mathrm{C}, \mathrm{Pd}-(\mathrm{Ni}-\mathrm{Zn}-\mathrm{P}) / \mathrm{C}$ and $\mathrm{Pd} / \mathrm{C}$ are much more active than the smooth $\mathrm{Pd}$ electrode and give different distributions of the oxidation products. $\mathrm{Pd} / \mathrm{C}$ is the most selective electrocatalyst yielding glycolate, while mixtures of glycolate (major $>60 \%$ ), oxalate and carbonate are obtained with $\mathrm{Pd}-(\mathrm{Ni}-\mathrm{Zn}) / \mathrm{C}$ or Pd-(Ni-Zn-P)/C. Carbonate is produced by oxidation of both glycolate (major contribution) and oxalate, while the major part of oxalate seems to be produced by the direct oxidation of EG (Scheme 3, route c). The Ni-Zn and Ni-Zn-P phases supporting the Pd clusters might favour the chelating adsorption of EG, leading to its direct oxidation to oxalate, by virtue of the oxophylic nature of both $\mathrm{Ni}$ and $\mathrm{Zn}$ [40].

In light of the results obtained in this work, current studies in our laboratories are aimed at developing MEAs with Pd-based anode electrodes and anion-exchange membranes for both passive and active DEGFCs.

\section{Acknowledgments}

We acknowledge the financial support from the European Commission (Network of Excellence IDECAT, contract n. NMP3-CT-2005-011730), Regione Toscana (Progetto CESARE) and the MIUR (Italy) for the PRIN 2007 project 200775CREC-004. Thanks are also due to the Guangdong Sci. \& Tech. Key Projects (2007A010700001, 2007B090400032) and Guangzhou Sci. \& Tech. Key Projects (2007Z1D0051.SKT[2007]17-11) for financial support. 


\section{References}

[1] W. Hauffe, J. Heitbaum, Electrochim. Acta 1978, 23, 299.

[2] F. Hahn, B. Beden, F. Kardigan, C. Lamy, J. Electroanal. Chem. 1987, 216, 169.

[3] L.-W. H. Leung, M. J. Weaver, J. Phys. Chem 1988, 92, 4019.

[4] P. A. Christensen, A. Hamnett, J. Electroanal. Chem. 1989, 260, 347.

[5] N. Dalbay, F. Kardigan, J. Electroanal. Chem. 1990, 296, 559.

[6] R. Pattabiram, Appl. Catal. A. General 1997, 153, 9.

[7] B. Wieland, J. P. Lancaster, C. S. Hoaglund, P. Holota, W. J. Tornquist, Lamgmuir 1996, 12, 2594.

[8] M. J. Gonzàlez, C. T. Hable, M. S. Wrighton, J. Phys. Chem. B 1998, 102, 9881.

[9] A. Dailey, J. Shin, C. Korzeniewski, Electrochim. Acta 1998, 44, 1147.

[10] E. Peled, T. Dudvedani, A. Ahra, Electrochem. Solid-State Lett. 2001, 4, A38.

[11] R. B. De Lima, V. Paganin, T. Iwasita, W. Vielstich, Electrochim. Acta 2003, 49, 85.

[12] K. Matsuoka, Y. Iriyama, T. Abe, M. Matsuoka, Z. Ogumi, Electrochim. Acta 2001, 51, 1085.

[13] Z. Wang, F. Hu, P. K. Shen, Electrochem. Commun. 2006, 8, 1764.

[14] H. Wang, Z. Jusys, R, J. Behm, J. Electroanal. Chem. 2006, 595, 23.

[15] P. K. Shen, C. Xu, Electrochem. Commun. 2006, 8, 184.

[16] C. Xu, Z. Tian, P. K. Shen, S. P. Jiang, Electrochim. Acta 2008, 53, 2610.

[17] K. Matsuoka, Y. Iriyama, T. Abe, M. Matsuoka, Z. Ogumi, J. Power Sources 2005, 150, 27.

[18] C. Coutanceau, L. Demarconnay, C. Lamy, J.-M Léger, J. Power Sources 2006, 156, 14.

[19] V. Livshits, E. Peled, J. Power Sources 2006, 161, 1187.

[20] L. Demarconnay, S. Brimaud, C. Coutanceau, J.-M- Léger, J. Electroanal. Chem. 2007, 601, 169.

[21] V. Livshits, M. Philosoph, E. Peled, J. Power Sources 2008, 178, 687.

[22] N. Ji, T. Zhang, M. Zheng, A. Wang, H. Wang, X. Wang, J. G. Chen, Angew. Chem. Int. Ed. Engl. 2008, 47,8510 .

[23] C. Cnobloch, D. Gröppel, H. Kohlmüller, D. Kühl, H. Poppa, G. Siemens, Progr. Batteries \& Solar Cells 1982, $4,225$.

[24] J. S. Spendelow, A. Wieckowski, Phys. Chem. Rev. Phys. 2007, 9, 2654.

[25] C. Bianchini, P. K. Shen, Chem. Rev. 2009, 109, 4183.

[26] J. R. Varcoe, R. C. T. Slade, E. L. H. Yee, Chem. Commun. 2006, 1428.

[27] J. R. Varcoe, R. C. T. Slade, Electrochem. Comm. 2006, 8, 839.

[28] J. R. Varcoe, R. C. T. Slade, E. L. H. Yee, D. D. Poynton, D. J. Driscoll, J. Power Sources 2007, 173, 194.

[29] T. Xu, J. Membr. Sci. 2005, 263, 1.

[30] J. Fang, P. K. Shen, J. Membrane Sci. 2006, 285, 317.

[31] H. Hou, G. Sun, R. He, Z. Wu, B. Sun, J. Power Sources 2008, 182, 95.

[32] K. Scott, E. Yu, G. Vlachogiannopoulos, M. Shivare, N. Duteanu, J. Power Sources 2008, 175, 452.

[33] E. Hao, K. Scott, J. Power Sources 2004, 137, 248.

[34] Y. Xiong, Q. L. Liu, A. M. Zhu, S. M. Huang, Q. H. Zeng, J. Power Sources 2009, 186, 328.

[35] E. Agel, J. Bouet, J. -F. Fauvarque, H. Yassir, H. Ann. Chim. Sci. Mat. 2001, 26, 59.

[36] H. Bunawaza, Y. Yamazaki, J. Power Sources 2008, 182, 48.

[37] F. Lu, J. Pan, A. Huang, L. Zhuang, J. T. Lu, PNAS 2008, 105, 20611.

[38] V. Bambagioni, C. Bianchini, A. Marchionni, J. Filippi, F. Vizza, J. Teddy, P. Serp, M. Zhiani, J. Power Sources 2009, 190, 241.

[39] V. Bambagioni, C. Bianchini, J. Filippi, A. Marchionni, F. Vizza, P. Bert, A. Tampucci, Electrochem. Commun. 2009, 11, 1077.

[40] V. Bambagioni, C. Bianchini, J. Filippi, W. Oberhauser, A. Marchionni, F. Vizza, R. Psaro, L. Sordelli, M. L. Foresti, M. Innocenti, ChemSusChem 2009, 2, 99.

[41] Z. X. Liang, T. S. Zhao, J. B. Xu, L. D. Zhu, Electrochim. Acta 2009, 54, 2203.

[42] G. F. Cui, S. Q. Song, P. K. Shen, A. Kowal, C. Bianchini, J. Phys. Chem. 2009, 113, 15639.

[43] E. Morallón, A. Rodes, J. L. Vázquez, J. M. Pérez, J. Electroanal. Chem. 1995, 391, 149.

[44] C. Bianchini, F. Vizza, P. K. Shen, manuscript in preparation. 


\section{Tables}

Table 1. Selected electrochemical parameters of EG oxidation on Pd-(Ni-Zn)/C, Pd-(Ni-Zn-P)/C and Pd/C electrodes in $2 \mathrm{M} \mathrm{KOH}$.

\begin{tabular}{cccccc}
\hline Catalyst & $\begin{array}{l}\mathrm{J}_{\mathrm{p}}, \\
\mathrm{mA} \mathrm{cm}\end{array}$ & $\begin{array}{c}\mathrm{Sa}_{\mathrm{p}} \\
\mathrm{mA}(\mu \\
\mathrm{gPd})^{-1}\end{array}$ & $\begin{array}{l}\mathrm{V}_{\text {onset }} \\
\mathrm{V}\end{array}$ & $\begin{array}{c}\mathrm{V}_{\mathrm{p}} \\
\mathrm{V}\end{array}$ & $\begin{array}{c}\text { Tafel slope } \mathrm{mV} \\
\mathrm{dec}^{-1}\end{array}$ \\
\hline $\begin{array}{c}\mathrm{Pd}-(\mathrm{Ni}- \\
\mathrm{Zn} / \mathrm{C}\end{array}$ & 84.2 & 3.33 & 0.37 & 1.02 & $205(\alpha 0.284)$ \\
$\mathrm{Pd}-(\mathrm{Ni}-$ & 65.5 & 2.46 & 0.42 & 0.95 & $190(\alpha 0.307)$ \\
$\begin{array}{c}\mathrm{Zn}-\mathrm{P}) / \mathrm{C} \\
\mathrm{Pd} / \mathrm{C}\end{array}$ & 84.5 & 3.15 & 0.42 & 0.95 & $180(\alpha 0.324)$ \\
& & & & &
\end{tabular}

\section{Figure captions}

Figure 1. Cyclic voltammograms on a Pd electrode of the following solutions: (a) $0.01 \mathrm{M} \mathrm{NaOH}+0.99 \mathrm{M}$ $\mathrm{NaClO}_{4}+1 \mathrm{M} \mathrm{EG}$; (b) $0.1 \mathrm{M} \mathrm{NaOH}+0.9 \mathrm{M} \mathrm{NaClO}_{4}+1 \mathrm{M} \mathrm{EG}$; (c) $1 \mathrm{M} \mathrm{NaOH}+1 \mathrm{M} \mathrm{EG}$; (d) $2 \mathrm{M} \mathrm{NaOH}+1$ M EG. Scan rate: $50 \mathrm{mV} \mathrm{s}^{-1}$

Figure 2. In situ FTIR spectra obtained under potential step polarization of the following solutions: (a) $0.01 \mathrm{M}$ $\mathrm{NaOH}+0.99 \mathrm{M} \mathrm{NaClO}_{4}+1 \mathrm{M} \mathrm{EG}$; (b) $0.1 \mathrm{M} \mathrm{NaOH}+0.9 \mathrm{M} \mathrm{NaClO}_{4}+1 \mathrm{M} \mathrm{EG}$; (c) $1 \mathrm{M} \mathrm{NaOH}+1 \mathrm{M} \mathrm{EG}$; (d) $2 \mathrm{M} \mathrm{NaOH}+1 \mathrm{M}$ EG. Scan number: 128 .

Figure 3. (A) Intensity of the band at $1580 \mathrm{~cm}^{-1}$ as a function of the polarization potential. (a) $0.01 \mathrm{M} \mathrm{NaOH}+$ $0.99 \mathrm{M} \mathrm{NaClO}_{4}+1 \mathrm{M} \mathrm{EG}$; (b) $0.1 \mathrm{M} \mathrm{NaOH}+0.9 \mathrm{M} \mathrm{NaClO}_{4}+1 \mathrm{M} \mathrm{EG}$; (c) $1 \mathrm{M} \mathrm{NaOH}+1 \mathrm{M} \mathrm{EG}$; (d) $2 \mathrm{M}$ $\mathrm{NaOH}+1 \mathrm{M}$ EG. (B) Intensity of the band at $1070 \mathrm{~cm}^{-1}$ as a function of the polarization potential. (a) $0.01 \mathrm{M}$ $\mathrm{NaOH}+0.99 \mathrm{M} \mathrm{NaClO}_{4}+1 \mathrm{M} \mathrm{EG}$; (b) $0.1 \mathrm{M} \mathrm{NaOH}+0.9 \mathrm{M} \mathrm{NaClO}_{4}+1 \mathrm{M} \mathrm{EG}$; (c) $1 \mathrm{M} \mathrm{NaOH}+1 \mathrm{M} \mathrm{EG}$; (d) $2 \mathrm{M} \mathrm{NaOH}+1 \mathrm{M} \mathrm{EG}$.

Figure 4. Cyclic voltammograms (at the tenth cycle) of EG oxidation on Pd-(Ni-Zn)/C, Pd-(Ni-Zn-P)/C and $\mathrm{Pd} / \mathrm{C}$ electrodes in $2 \mathrm{M} \mathrm{KOH}$ and $5 \mathrm{wt} \% \mathrm{EG}$. Scan rate: $50 \mathrm{mV} \mathrm{s}^{-1}$.

Scheme 1. Proposed mechanism for the electrooxidation of EG to glycolate acid on Pd in alkaline media.

Figure 5. Plots of the anodic peak specific current density against the square-root of the scan rate for the oxidation of EG (5 wt\%) on Pd-(Ni-Zn)/C, Pd-(Ni-Zn-P)/C and Pd/C in $2 \mathrm{M} \mathrm{KOH.}$

Scheme 2. Overall reaction scheme of EG oxidation on metal electrocatalysyts in alkaline media. Products in boxes have been isolated; products in circles have been detected spectroscopically.

Figure 6. Cyclic voltammograms of (A) glycolic acid (2 wt\%) and (B) glyoxylic acid (2 wt\%) oxidation on Pd(Ni-Zn)/C, Pd-(Ni-Zn-P)/C and Pd/C in $2 \mathrm{M} \mathrm{KOH}$. Scan rate: $50 \mathrm{mV} \mathrm{s}^{-1}$.

Scheme 3. Direct and sequential routes for the electrooxidation of EG to oxalic acid.

Figure 7. Cyclic voltammograns of $\mathrm{Pd}-(\mathrm{Ni}-\mathrm{Zn}) / \mathrm{C}, \mathrm{Pd}-(\mathrm{Ni}-\mathrm{Zn}-\mathrm{P}) / \mathrm{C}$ and $\mathrm{Pd} / \mathrm{C}$ in $2 \mathrm{M} \mathrm{KOH}$ or in $2 \mathrm{M} \mathrm{KOH}+2$ wt $\%$ oxalic acid. Scan rate: $50 \mathrm{mV} \mathrm{s}^{-1}$. 


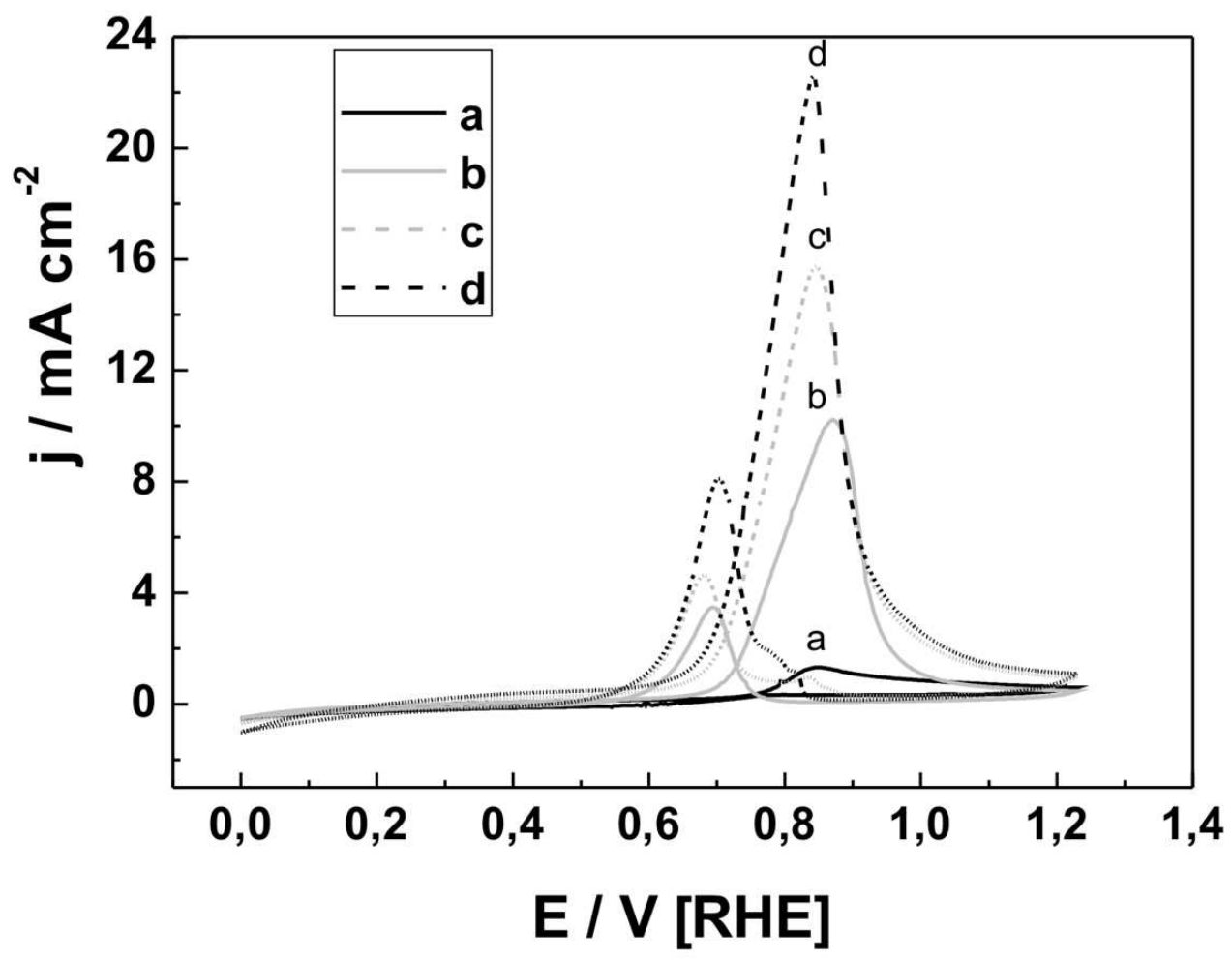

Figure 1. Cyclic voltammograms on a Pd electrode of the following solutions: (a) $0.01 \mathrm{M} \mathrm{NaOH}+$ $0.99 \mathrm{M} \mathrm{NaClO} 4$ + $1 \mathrm{M} \mathrm{EG}$; (b) $0.1 \mathrm{M} \mathrm{NaOH}+0.9 \mathrm{M} \mathrm{NaClO} 4+1 \mathrm{M} \mathrm{EG}$; (c) $1 \mathrm{M} \mathrm{NaOH}+1 \mathrm{M} \mathrm{EG}$; (d) $2 \mathrm{M} \mathrm{NaOH}+1 \mathrm{M}$ EG. Scan rate: $50 \mathrm{mV} \mathrm{s}-1$ $74 \times 57 \mathrm{~mm}(400 \times 400 \mathrm{DPI})$ 
(a)

EIV

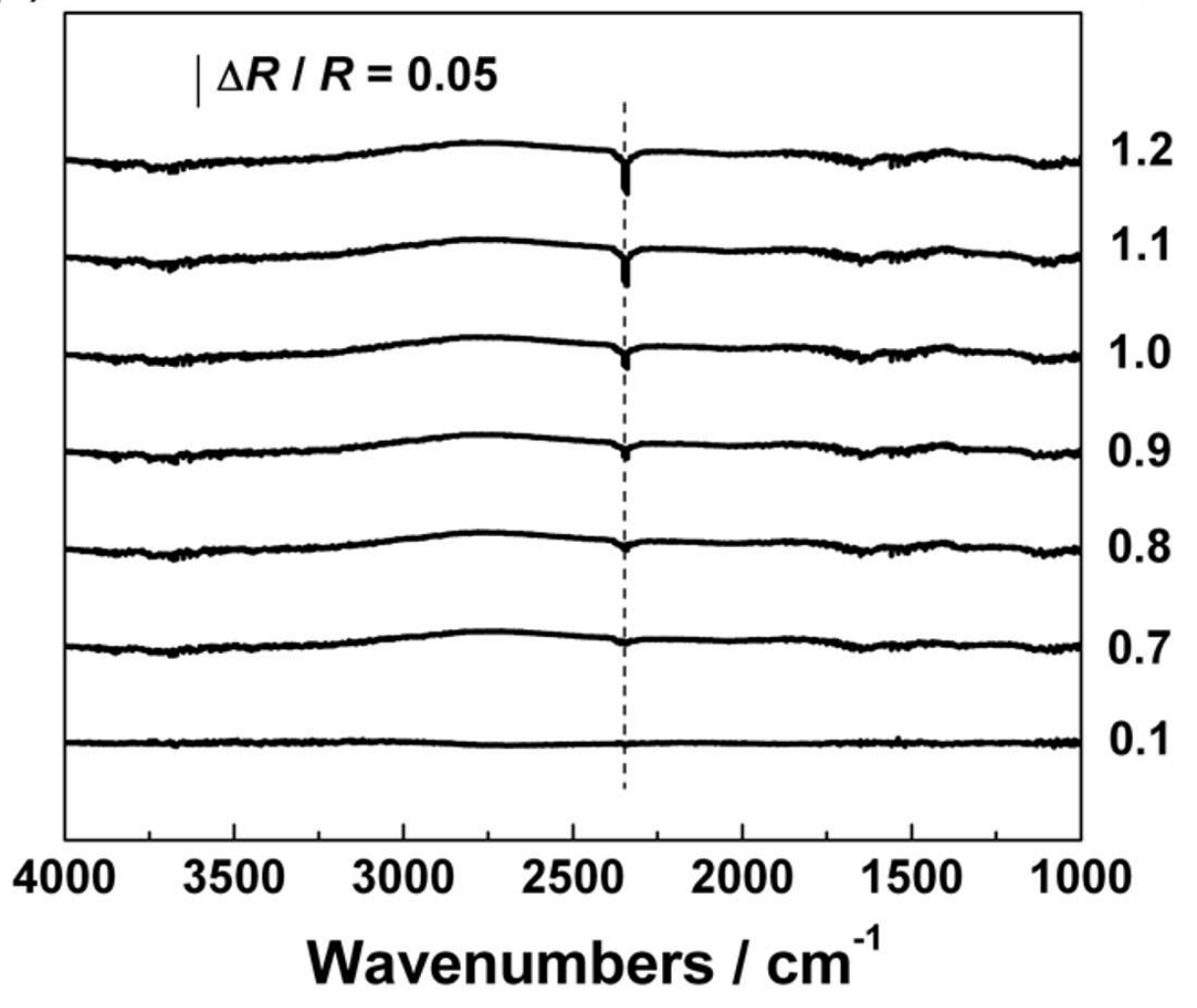

Figure 2. In situ FTIR spectra obtained under potential step polarization of the following solutions: (a) $0.01 \mathrm{M} \mathrm{NaOH}+0.99 \mathrm{M} \mathrm{NaClO} 4+1 \mathrm{M} \mathrm{EG}$; (b) $0.1 \mathrm{M} \mathrm{NaOH}+0.9 \mathrm{M} \mathrm{NaClO} 4+1 \mathrm{M} \mathrm{EG}$; (c) $1 \mathrm{M}$ $\mathrm{NaOH}+1 \mathrm{M} \mathrm{EG}$; (d) $2 \mathrm{M} \mathrm{NaOH}+1 \mathrm{M} \mathrm{EG}$. Scan number: 128.

$74 \times 65 \mathrm{~mm}(400 \times 400 \mathrm{DPI})$ 
(b)

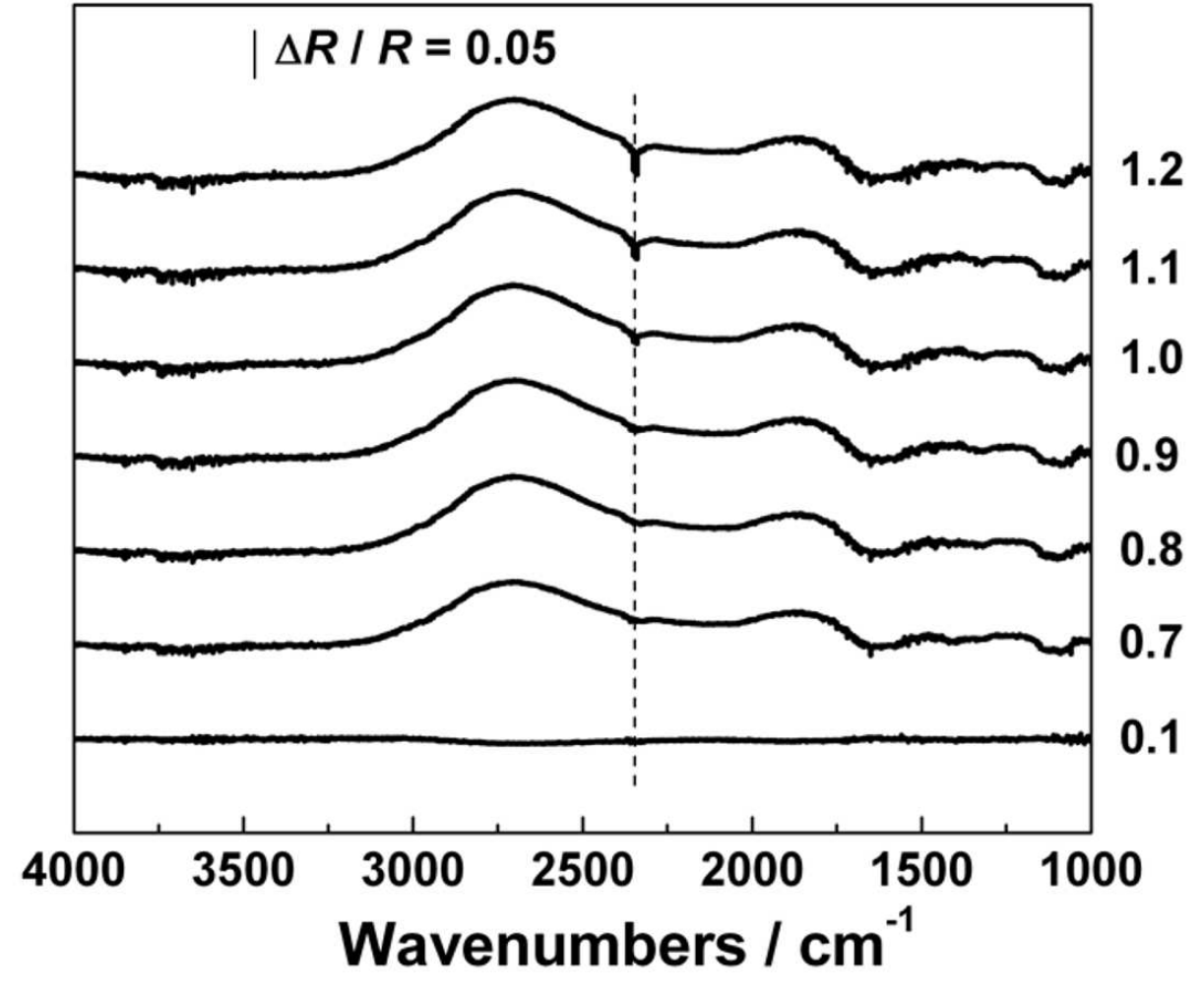

Figure 2. In situ FTIR spectra obtained under potential step polarization of the following solutions: (a) $0.01 \mathrm{M} \mathrm{NaOH}+0.99 \mathrm{M} \mathrm{NaClO} 4+1 \mathrm{M} \mathrm{EG}$; (b) $0.1 \mathrm{M} \mathrm{NaOH}+0.9 \mathrm{M} \mathrm{NaClO} 4+1 \mathrm{M} \mathrm{EG}$; (c) $1 \mathrm{M}$ $\mathrm{NaOH}+1 \mathrm{M} \mathrm{EG}$; (d) $2 \mathrm{M} \mathrm{NaOH}+1 \mathrm{M}$ EG. Scan number: 128. $74 \times 65 \mathrm{~mm}(400 \times 400 \mathrm{DPI})$ 
(c)

$E / V$

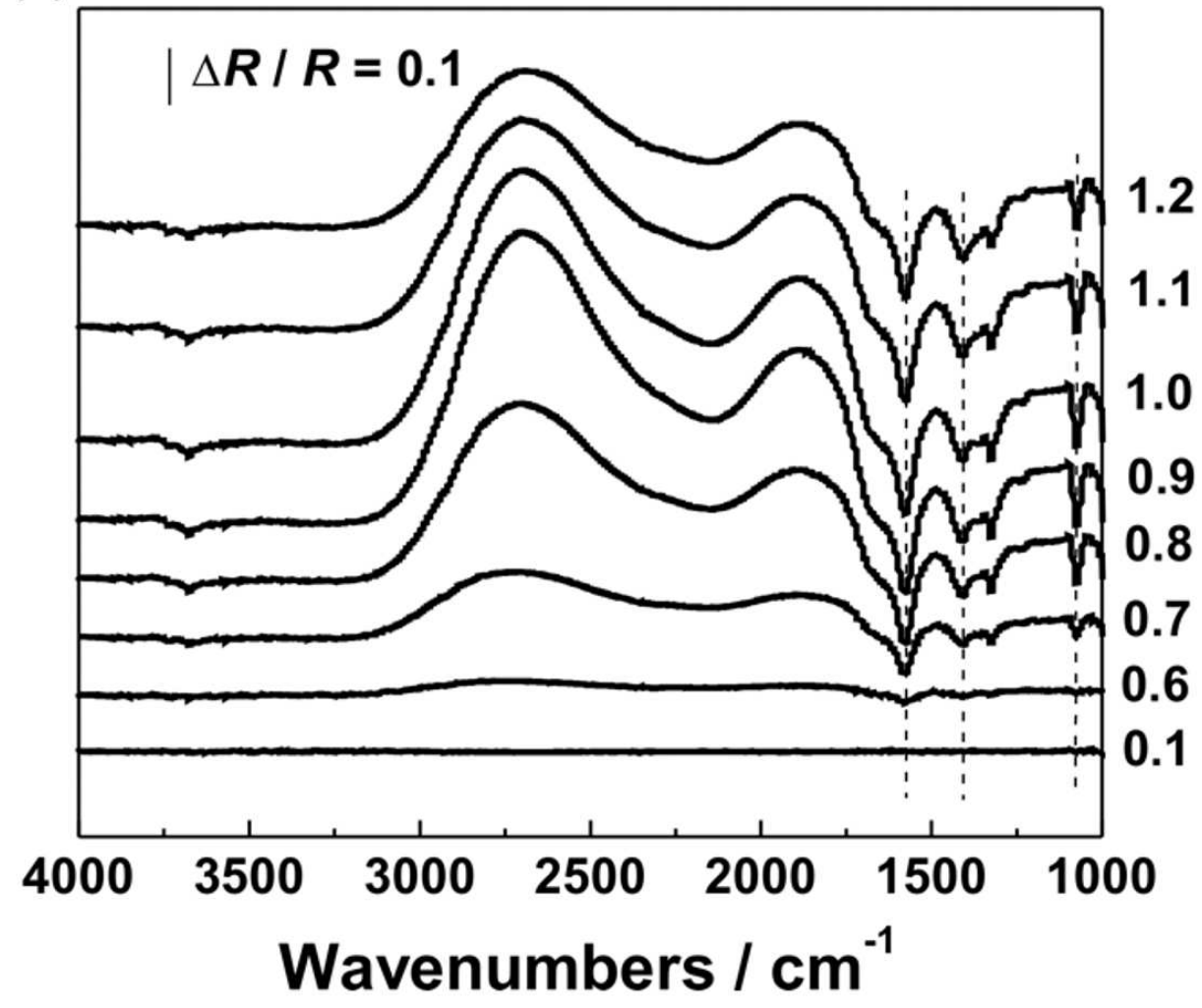

Figure 2. In situ FTIR spectra obtained under potential step polarization of the following solutions: (a) $0.01 \mathrm{M} \mathrm{NaOH}+0.99 \mathrm{M} \mathrm{NaClO} 4+1 \mathrm{M} \mathrm{EG}$; (b) $0.1 \mathrm{M} \mathrm{NaOH}+0.9 \mathrm{M} \mathrm{NaClO} 4+1 \mathrm{M} \mathrm{EG}$; (c) $1 \mathrm{M}$ $\mathrm{NaOH}+1$ M EG; (d) 2 M NaOH + 1 M EG. Scan number: 128 . $74 \times 65 \mathrm{~mm}(400 \times 400 \mathrm{DPI})$ 
(d)

$E I V$

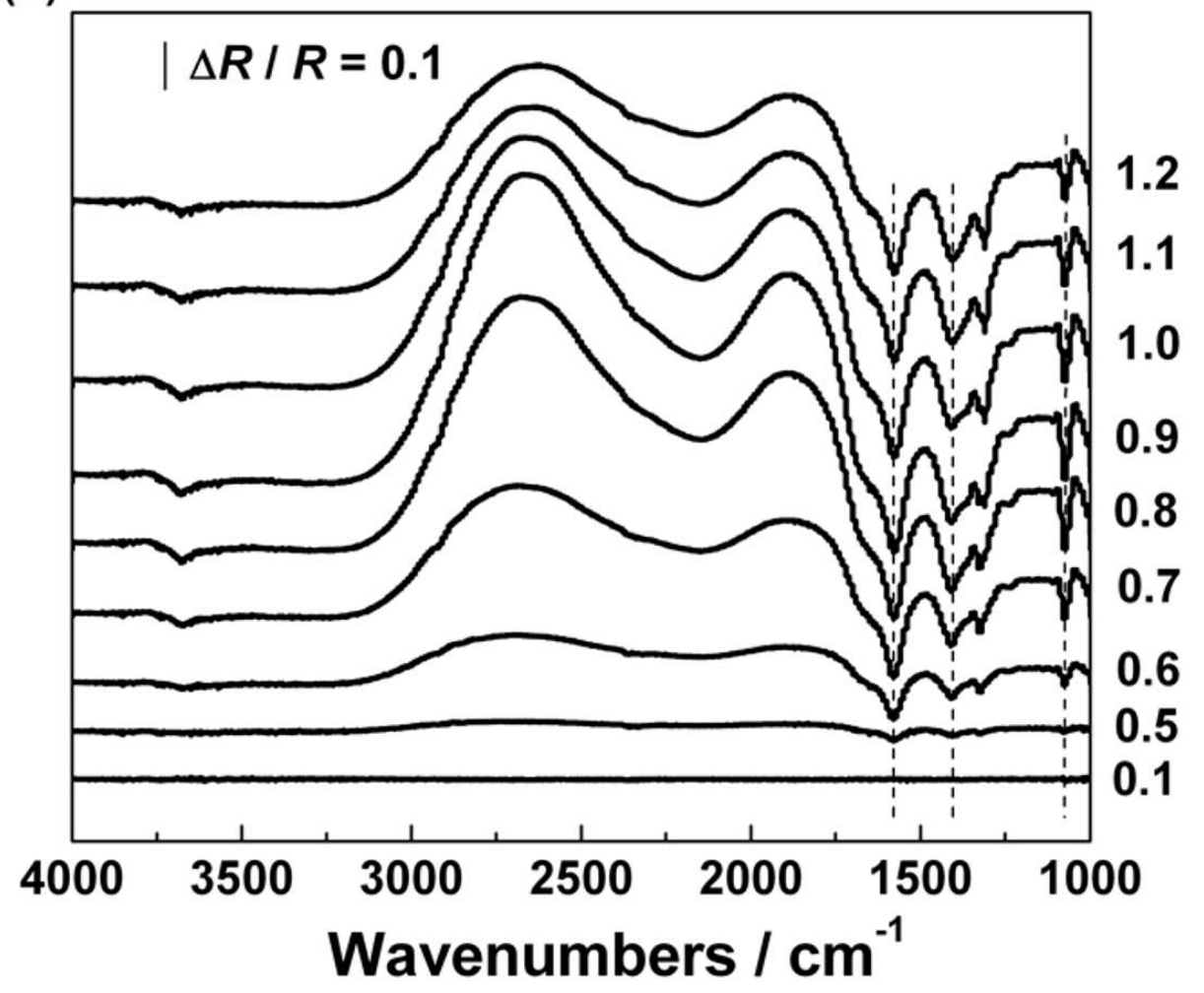

Figure 2. In situ FTIR spectra obtained under potential step polarization of the following solutions: (a) $0.01 \mathrm{M} \mathrm{NaOH}+0.99 \mathrm{M} \mathrm{NaClO} 4+1 \mathrm{M} \mathrm{EG}$; (b) $0.1 \mathrm{M} \mathrm{NaOH}+0.9 \mathrm{M} \mathrm{NaClO} 4+1 \mathrm{M} \mathrm{EG}$; (c) $1 \mathrm{M}$ $\mathrm{NaOH}+1 \mathrm{M} \mathrm{EG}$; (d) $2 \mathrm{M} \mathrm{NaOH}+1 \mathrm{M} \mathrm{EG}$. Scan number: 128. $74 \times 65 \mathrm{~mm}(400 \times 400 \mathrm{DPI})$ 


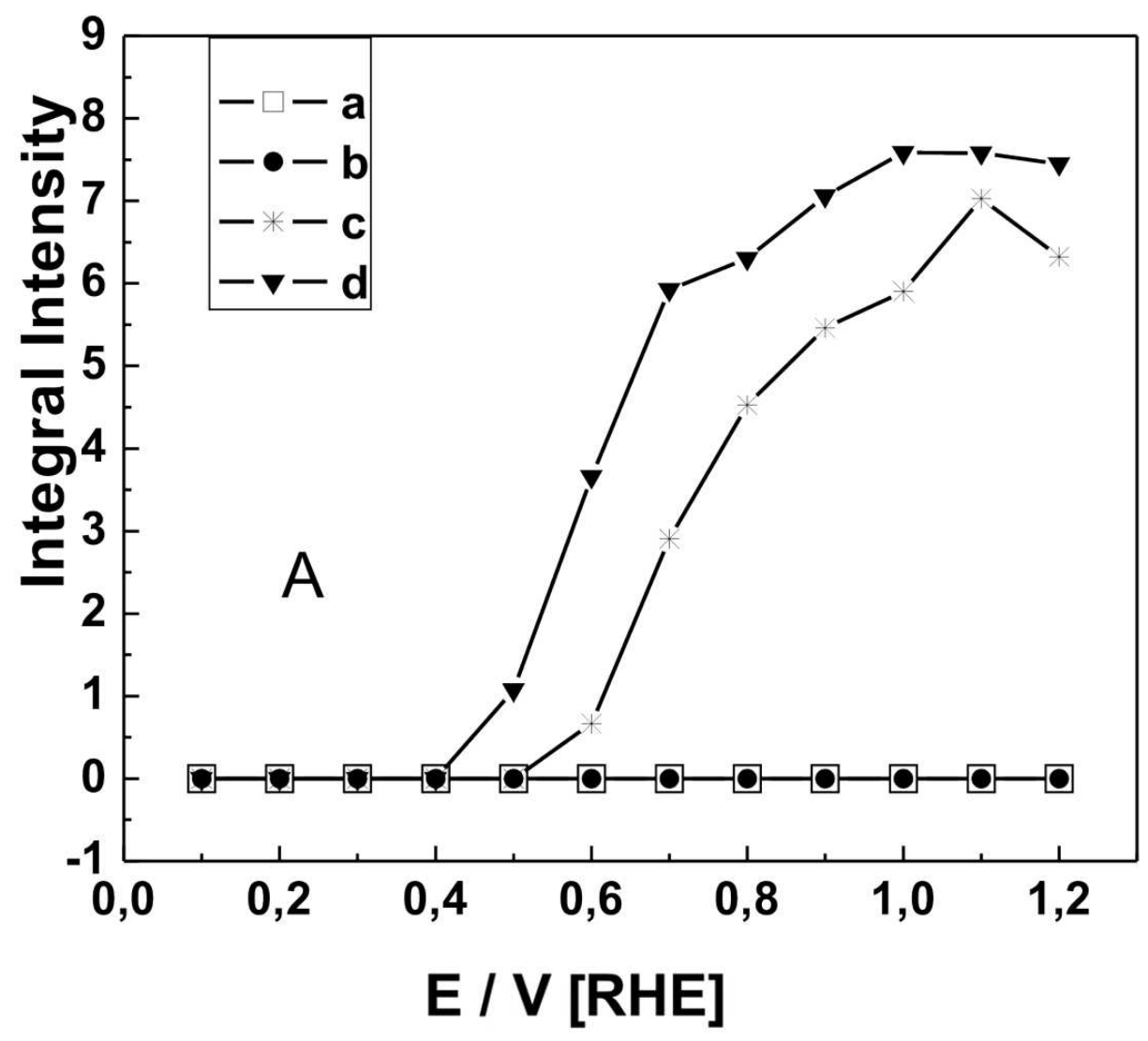

Figure 3. (A) Intensity of the band at $1580 \mathrm{~cm}-1$ as a function of the polarization potential. (a) 0.01 $\mathrm{M} \mathrm{NaOH}+0.99 \mathrm{M} \mathrm{NaClO} 4+1 \mathrm{M} \mathrm{EG}$; (b) $0.1 \mathrm{M} \mathrm{NaOH}+0.9 \mathrm{M} \mathrm{NaClO} 4+1 \mathrm{M} \mathrm{EG}$; (c) $1 \mathrm{M} \mathrm{NaOH}+1$ M EG; (d) $2 \mathrm{M} \mathrm{NaOH}+1 \mathrm{M} \mathrm{EG}$. (B) Intensity of the band at $1070 \mathrm{~cm}-1$ as a function of the polarization potential. (a) $0.01 \mathrm{M} \mathrm{NaOH}+0.99 \mathrm{M} \mathrm{NaClO} 4+1 \mathrm{M} \mathrm{EG}$; (b) $0.1 \mathrm{M} \mathrm{NaOH}+0.9 \mathrm{M}$ $\mathrm{NaClO} 4+1 \mathrm{M} \mathrm{EG}$; (c) $1 \mathrm{M} \mathrm{NaOH}+1 \mathrm{M} \mathrm{EG}$; (d) $2 \mathrm{M} \mathrm{NaOH}+1 \mathrm{M} \mathrm{EG}$. $74 \times 65 \mathrm{~mm}(400 \times 400$ DPI $)$ 


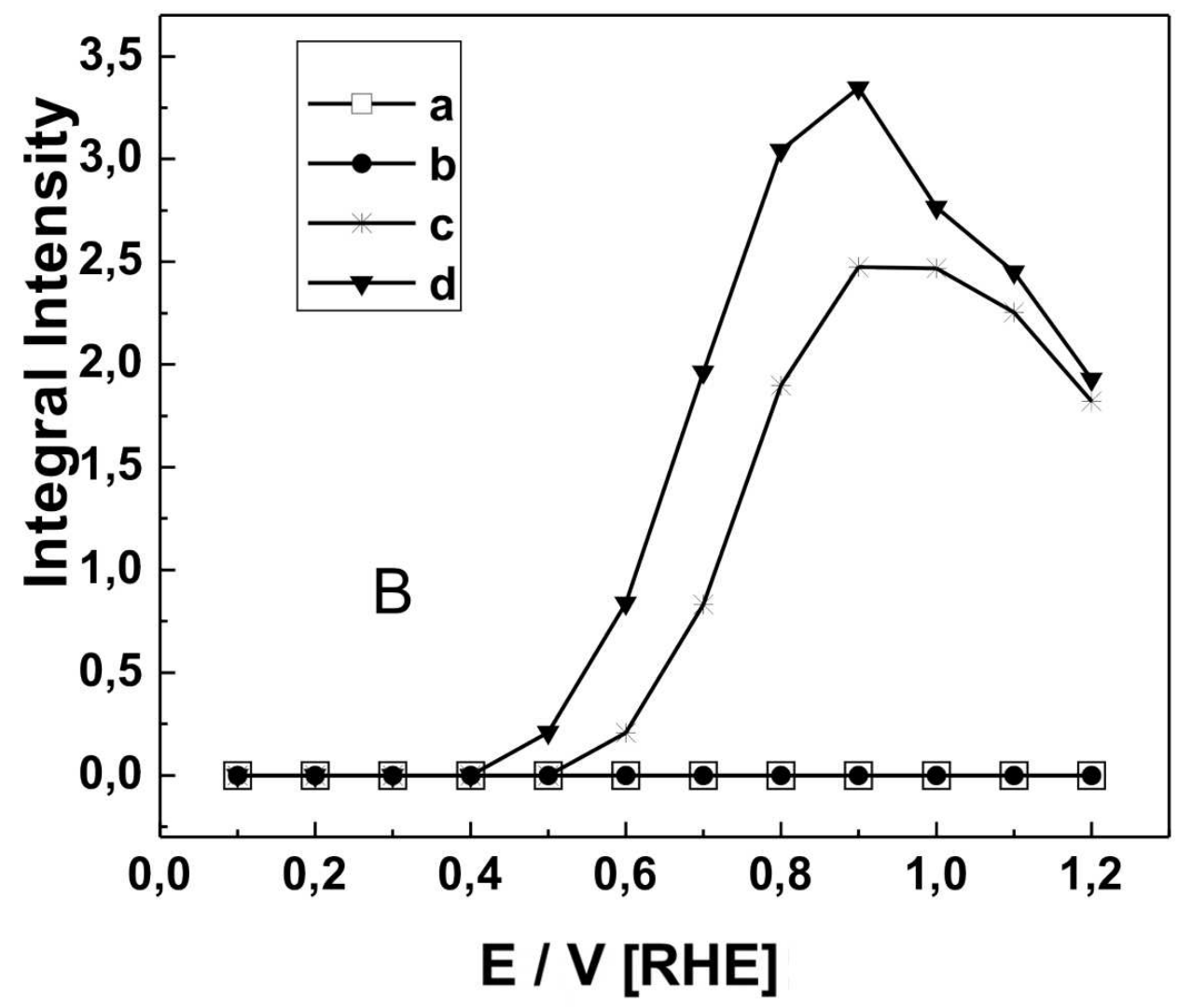

Figure 3. (A) Intensity of the band at $1580 \mathrm{~cm}-1$ as a function of the polarization potential. (a) 0.01 $\mathrm{M} \mathrm{NaOH}+0.99 \mathrm{M} \mathrm{NaClO} 4$ + $1 \mathrm{M} \mathrm{EG}$; (b) $0.1 \mathrm{M} \mathrm{NaOH}+0.9 \mathrm{M} \mathrm{NaClO} 4+1 \mathrm{M} \mathrm{EG}$; (c) $1 \mathrm{M} \mathrm{NaOH}+1$ M EG; (d) $2 \mathrm{M} \mathrm{NaOH}+1 \mathrm{M} \mathrm{EG}$. (B) Intensity of the band at $1070 \mathrm{~cm}-1$ as a function of the polarization potential. (a) $0.01 \mathrm{M} \mathrm{NaOH}+0.99 \mathrm{M} \mathrm{NaClO} 4+1 \mathrm{M} \mathrm{EG}$; (b) $0.1 \mathrm{M} \mathrm{NaOH}+0.9 \mathrm{M}$ $\mathrm{NaClO} 4+1 \mathrm{M} \mathrm{EG}$; (c) $1 \mathrm{M} \mathrm{NaOH}+1 \mathrm{M} \mathrm{EG}$; (d) $2 \mathrm{M} \mathrm{NaOH}+1 \mathrm{M} \mathrm{EG}$. 


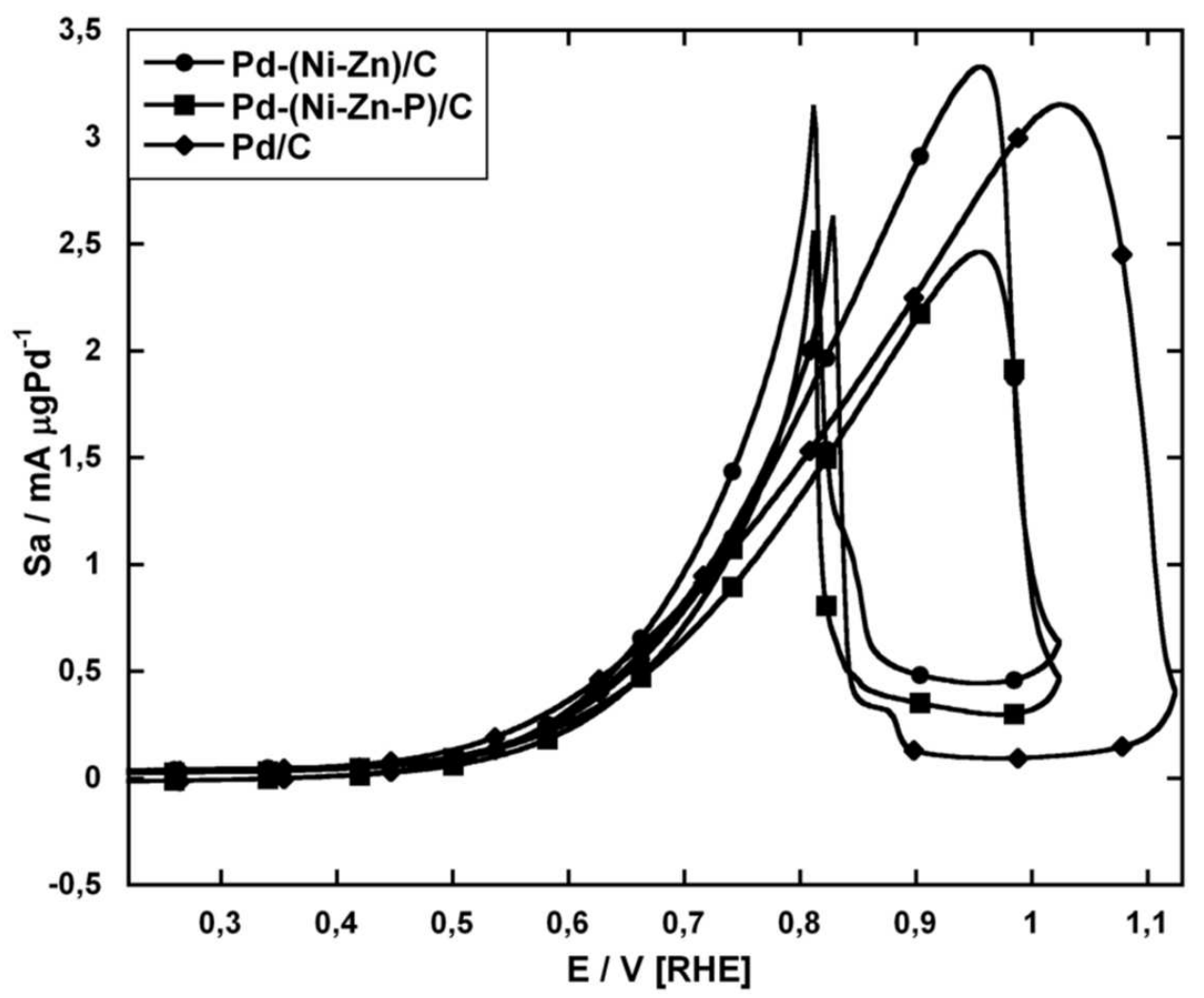

Figure 4. Cyclic voltammograms (at the tenth cycle) of EG oxidation on Pd-(Ni-Zn)/C, Pd-(Ni-Zn$\mathrm{P}) / \mathrm{C}$ and $\mathrm{Pd} / \mathrm{C}$ electrodes in $2 \mathrm{M} \mathrm{KOH}$ and $5 \mathrm{wt} \% \mathrm{EG}$. Scan rate: $50 \mathrm{mV} \mathrm{s}-1$. $74 \times 65 \mathrm{~mm}(400 \times 400 \mathrm{DPI})$ 

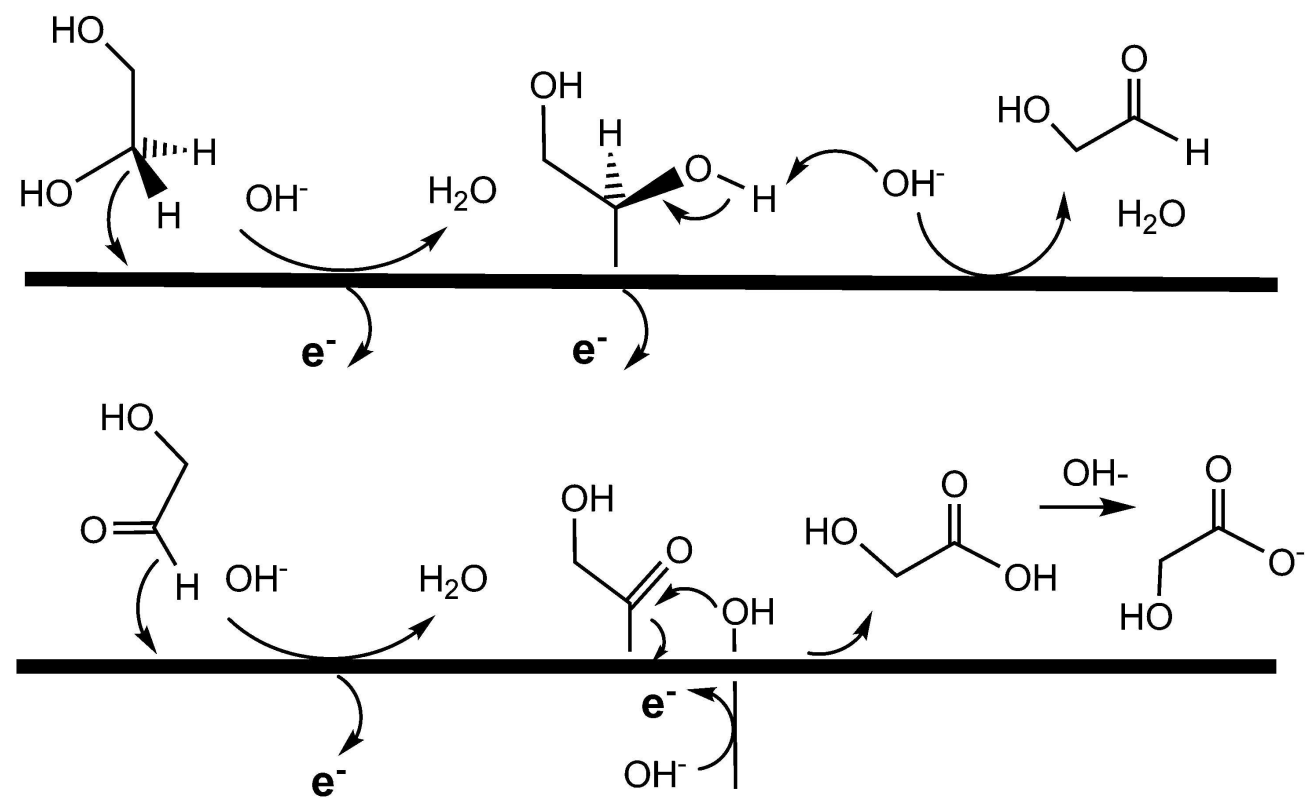

Scheme 1. Proposed mechanism for the electrooxidation of EG to glycolate acid on Pd in alkaline media.

\section{$125 \times 77 \mathrm{~mm}(600 \times 600$ DPI $)$}




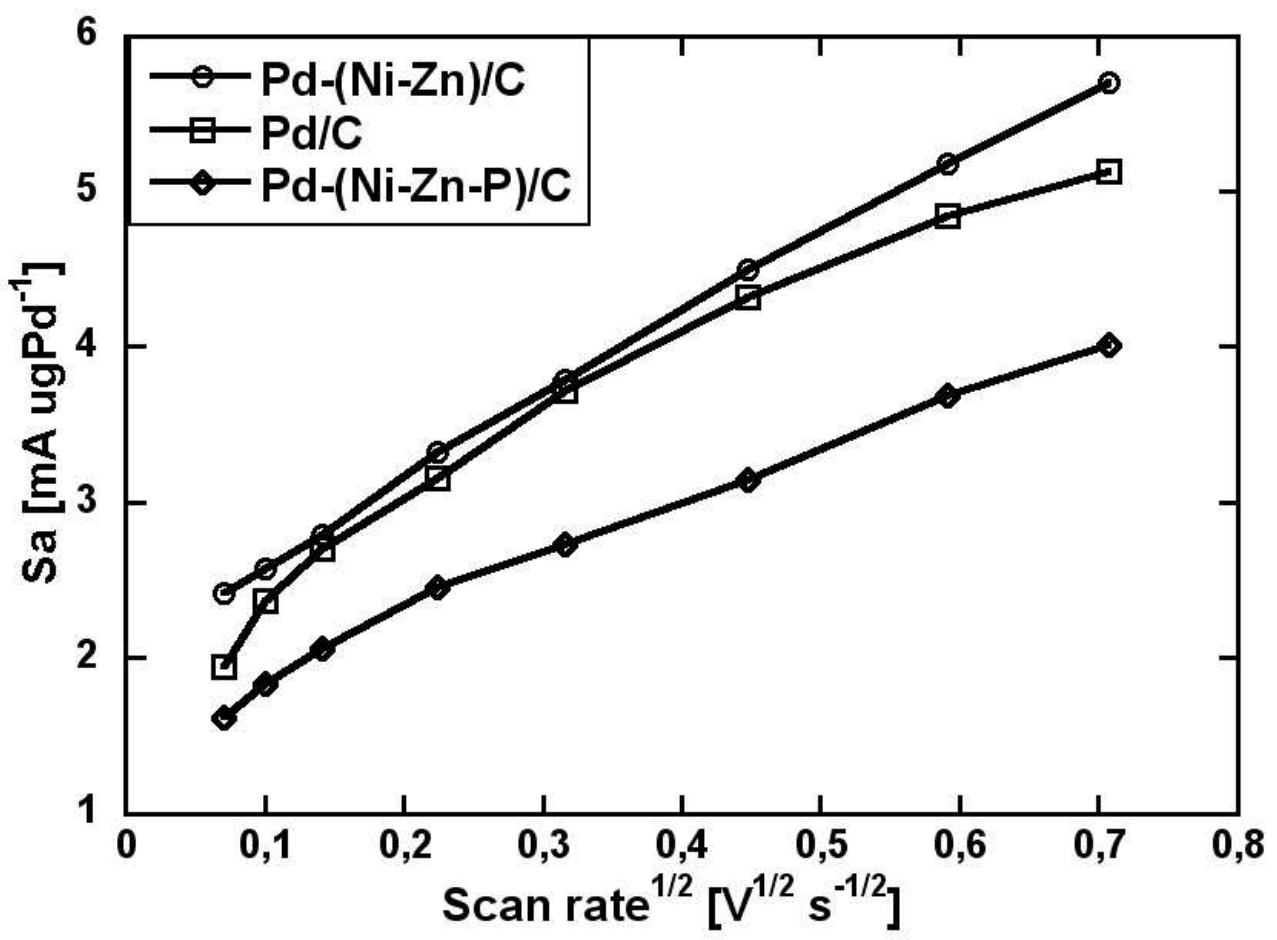

Figure 5. Plots of the anodic peak specific current density against the square-root of the scan rate for the oxidation of EG (5 wt\%) on Pd-(Ni-Zn)/C, Pd-(Ni-Zn-P)/C and Pd/C in $2 \mathrm{M} \mathrm{KOH}$. $74 \times 54 \mathrm{~mm}(288 \times 288$ DPI $)$ 
1

2

3

4

5

6

7

8

9

10

11

12

13

14

15

16

17

18

19

20

21

22

23

24

25

26

27

28

29

30

31

32

33

34

35

36

37

38

39

40

41

42

43

44

45

46

47

48

49

50

51

52

53

54

55

56

57

58

59

60

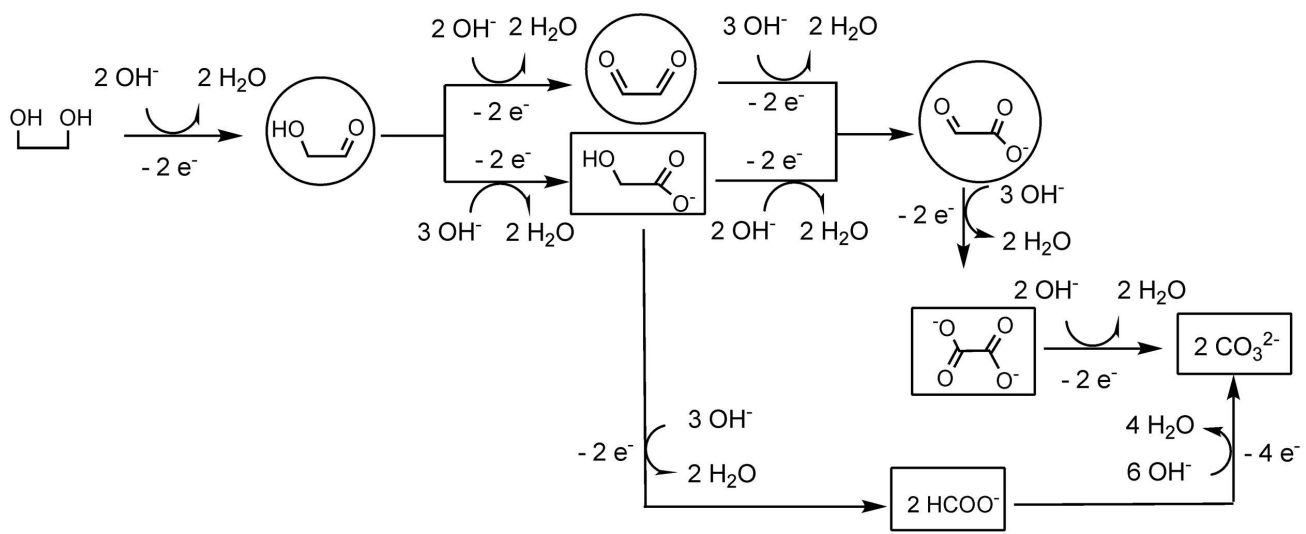

Scheme 2. Overall reaction scheme of EG oxidation on metal electrocatalysyts in alkaline media. Products in boxes have been isolated; products in circles have been detected spectroscopically. $160 \times 65 \mathrm{~mm}(400 \times 400 \mathrm{DPI})$ 


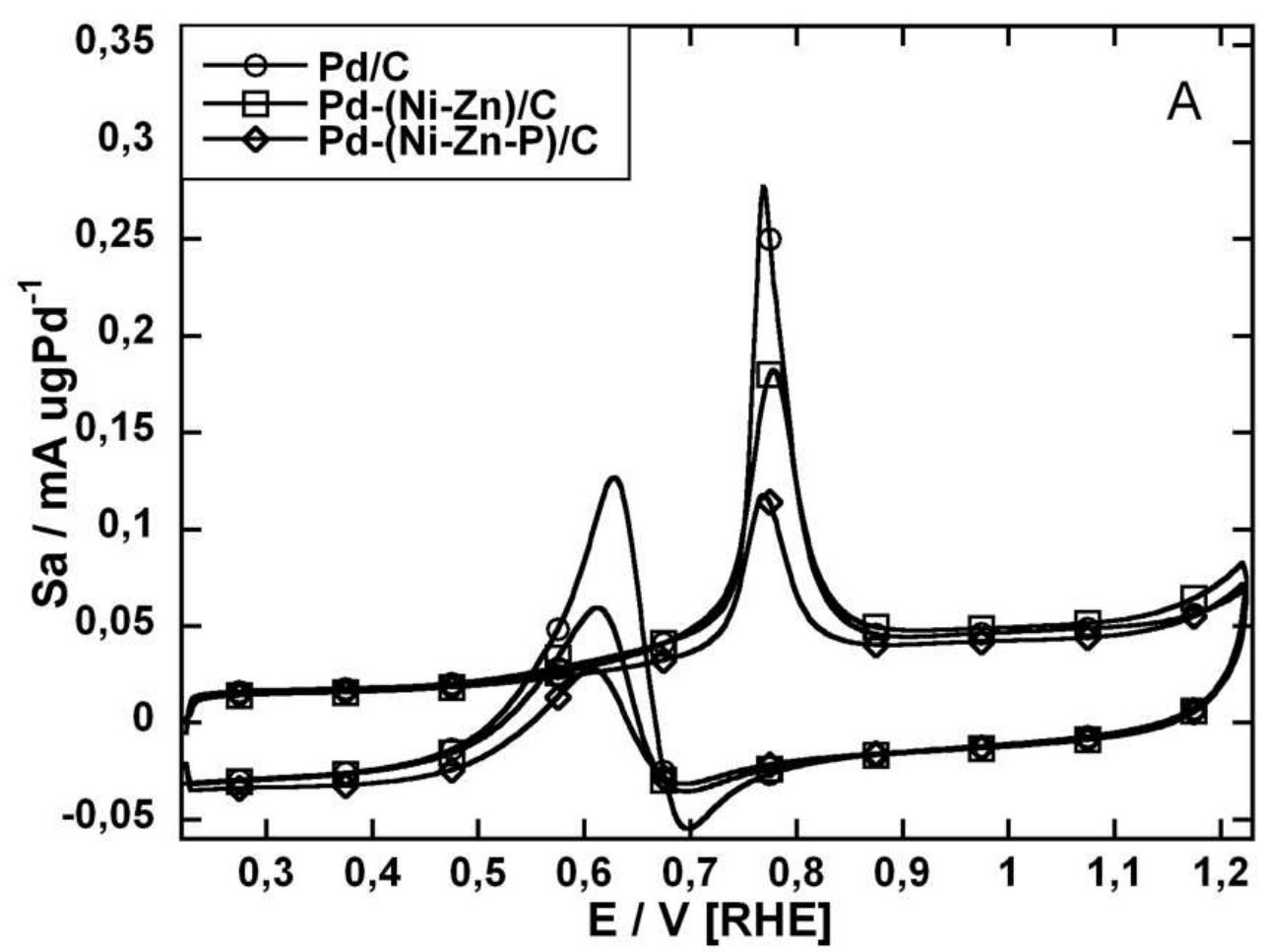

Figure 6. Cyclic voltammograms of (A) glycolic acid (2 wt\%) and (B) glyoxylic acid (2 wt\%) oxidation on $\mathrm{Pd}-(\mathrm{Ni}-\mathrm{Zn}) / \mathrm{C}, \mathrm{Pd}-(\mathrm{Ni}-\mathrm{Zn}-\mathrm{P}) / \mathrm{C}$ and $\mathrm{Pd} / \mathrm{C}$ in $2 \mathrm{M} \mathrm{KOH}$. Scan rate: $50 \mathrm{mV} \mathrm{s}-1$. $75 \times 57 \mathrm{~mm}(300 \times 300 \mathrm{DPI})$ 


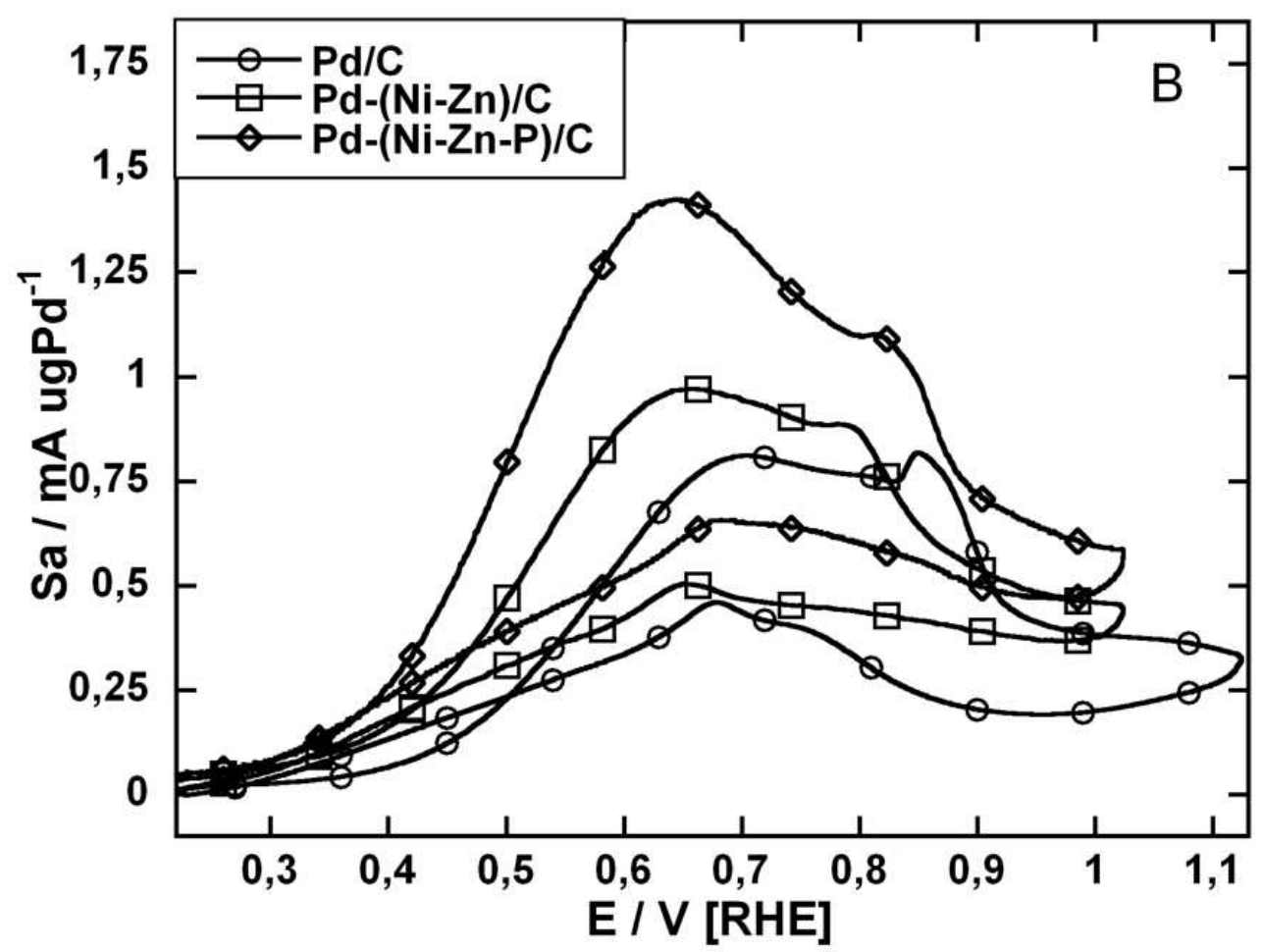

Figure 6. Cyclic voltammograms of (A) glycolic acid (2 wt\%) and (B) glyoxylic acid (2 wt\%) oxidation on $\mathrm{Pd}-(\mathrm{Ni}-\mathrm{Zn}) / \mathrm{C}, \mathrm{Pd}-(\mathrm{Ni}-\mathrm{Zn}-\mathrm{P}) / \mathrm{C}$ and $\mathrm{Pd} / \mathrm{C}$ in $2 \mathrm{M} \mathrm{KOH}$. Scan rate: $50 \mathrm{mV} \mathrm{s}-1$. $75 \times 57 \mathrm{~mm}(300 \times 300 \mathrm{DPI})$ 


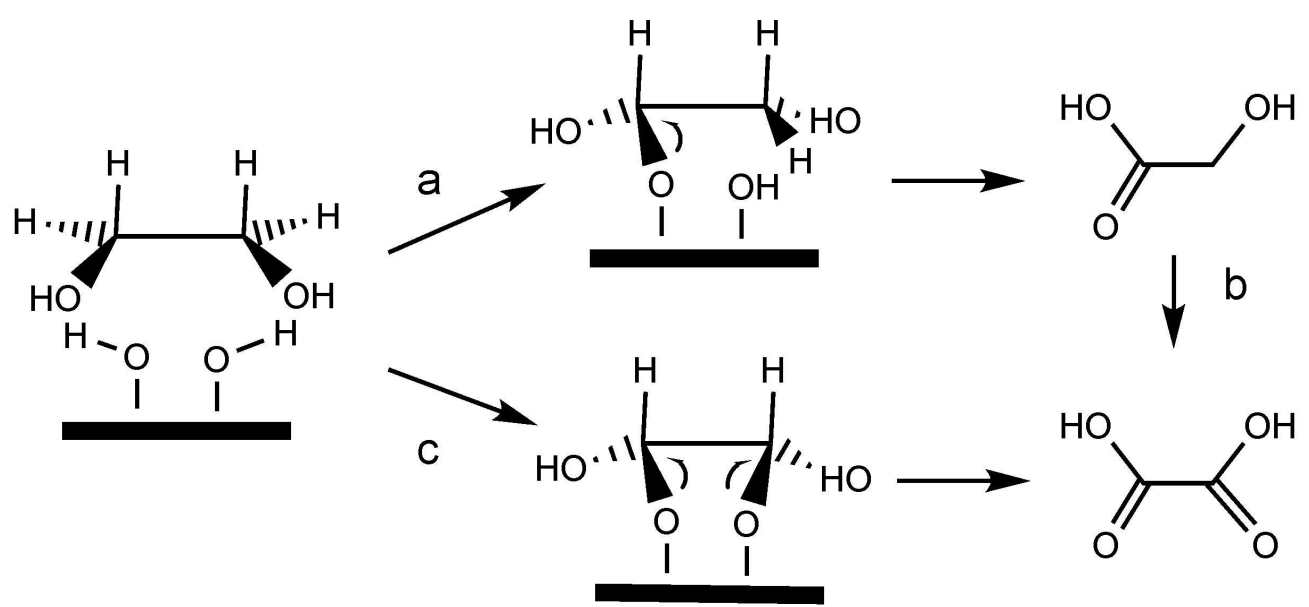

Scheme 3. Direct and sequential routes for the electrooxidation of EG to oxalic acid. $103 \times 48 \mathrm{~mm}(600 \times 600 \mathrm{DPI})$ 


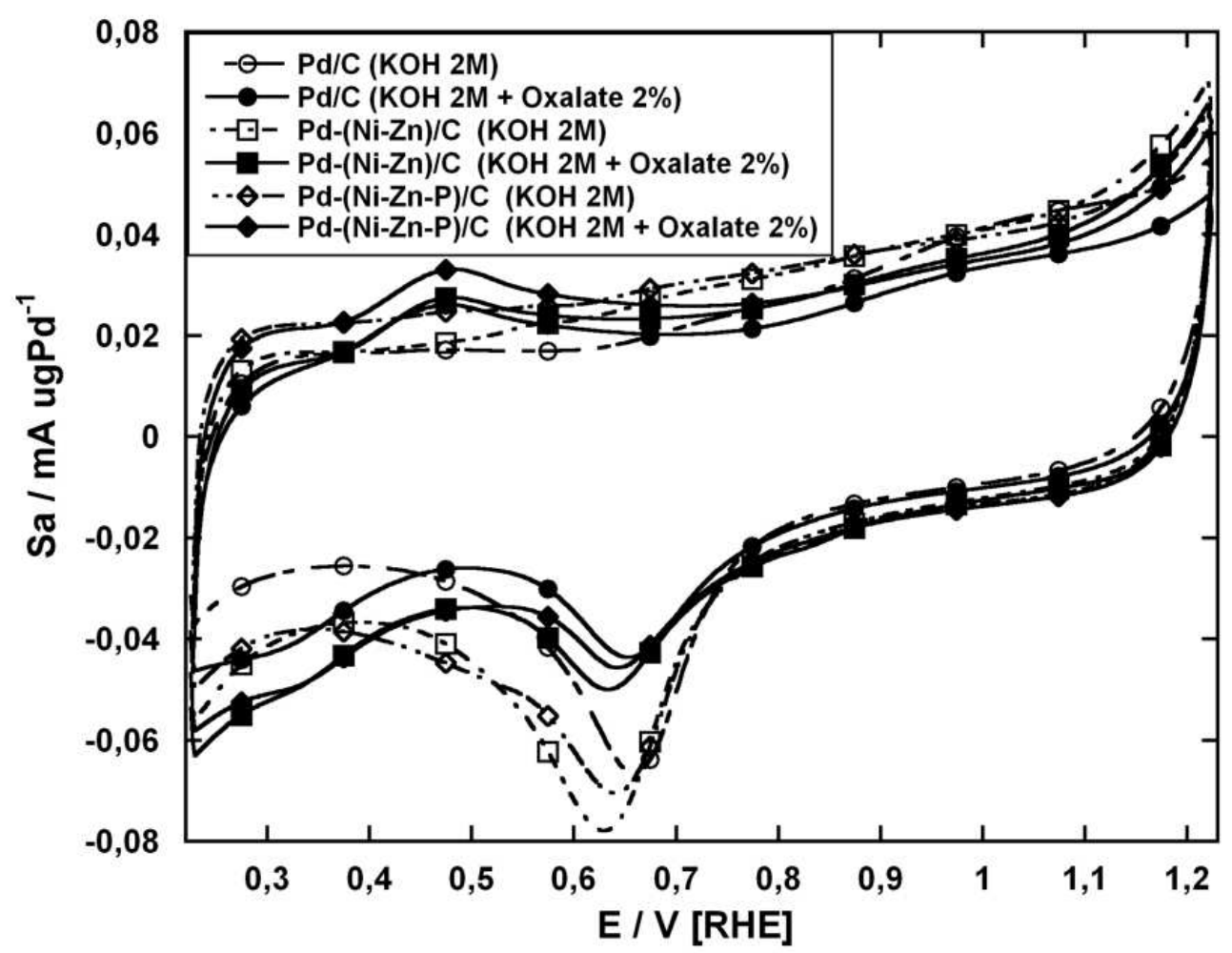

Figure 7. Cyclic voltammograns of $\mathrm{Pd}-(\mathrm{Ni}-\mathrm{Zn}) / \mathrm{C}, \mathrm{Pd}-(\mathrm{Ni}-\mathrm{Zn}-\mathrm{P}) / \mathrm{C}$ and $\mathrm{Pd} / \mathrm{C}$ in $2 \mathrm{M} \mathrm{KOH}$ or in $2 \mathrm{M}$ $\mathrm{KOH}+2 \mathrm{wt} \%$ oxalic acid. Scan rate: $50 \mathrm{mV} \mathrm{s}-1$. $75 \times 57 \mathrm{~mm}(300 \times 300 \mathrm{DPI})$ 